\title{
Review \\ Beyond RAS and BRAF: HER2, a New Actionable Oncotarget in Advanced Colorectal Cancer
}

\author{
Chiara Guarini ${ }^{1,2, *(\mathbb{D})}$, Teresa Grassi ${ }^{2}$, Gaetano Pezzicoli ${ }^{1,2}(\mathbb{B})$ and Camillo Porta ${ }^{2,3}(\mathbb{C}$ \\ 1 Post-Graduate School of Specialization in Medical Oncology, University of Bari 'Aldo Moro', 70124 Bari, Italy; \\ pezzicoligaet@gmail.com \\ 2 Division of Medical Oncology, A.O.U. Consorziale Policlinico di Bari, 70124 Bari, Italy; \\ teresa.grassi@libero.it (T.G.); camillo.porta@gmail.com (C.P.) \\ 3 Chair of Oncology, Department of Biomedical Sciences and Human Oncology, University of Bari 'A. Moro', \\ 70124 Bari, Italy \\ * Correspondence: chiara.guarini@outlook.it
}

Citation: Guarini, C.; Grassi, T.;

Pezzicoli, G.; Porta, C. Beyond RAS and BRAF: HER2, a New Actionable Oncotarget in Advanced Colorectal Cancer. Int. J. Mol. Sci. 2021, 22, 6813. https://doi.org/10.3390/ ijms22136813

Academic Editor: Sun-Hee Leem

Received: 31 May 2021

Accepted: 22 June 2021

Published: 24 June 2021

Publisher's Note: MDPI stays neutral with regard to jurisdictional claims in published maps and institutional affiliations.

Copyright: (c) 2021 by the authors. Licensee MDPI, Basel, Switzerland. This article is an open access article distributed under the terms and conditions of the Creative Commons Attribution (CC BY) license (https:// creativecommons.org/licenses/by/ $4.0 /)$

\begin{abstract}
The human epidermal growth factor receptor 2 (HER2) is a well-established oncogenic driver and a successful therapeutic target in several malignancies, such as breast and gastric cancers. HER2 alterations, including amplification and somatic mutations, have also been detected in a small but not negligible subset of patients affected by advanced colorectal cancer (aCRC). However, to date, there are no available oncotargets in this malignancy beyond RAS and BRAF that are available. Here we present an overview on the present predictive and prognostic role of HER2 expression in aCRC, as well as on its consequent potential therapeutic implications from preclinical investigations towards ongoing trials testing anti-HER2 agents in aCRC. While HER2's role as a molecular predictive biomarker for anti-EGFR therapies in CRC is recognized, HER2 prognostic value remains controversial. Moreover, thanks to the impressive and growing body of clinical evidence, HER2 is strongly emerging as a new potential actionable oncotarget in aCRC. In conclusion, in the foreseeable future, HER2-targeted therapeutic strategies may integrate the algorithm of aCRC treatment towards an increasingly tailored therapeutic approach to this disease.
\end{abstract}

Keywords: colorectal cancer; HER2; targeted therapy

\section{Introduction}

The treatment of patients with advanced colorectal cancer (aCRC) still relies on the administration of systemic therapies (chemotherapy combined with either antiangiogenics or anti-EGFR agents) with a mainly palliative intent [1]. Recently, clear benefits of a multidisciplinary approach, such as combinations of surgical resection and other locoregional techniques (with or without systemic treatments), have been established for a oligometastatic disease [2,3]. Furthermore, in the recent past, immunotherapy has emerged as a practice-changing treatment [4-8], with Pembrolizumab having received the US Food and Drug Administration (FDA) approval as an up-front treatment for unresectable or metastatic CRC (mCRC) with high microsatellite instability (MSI-H) or mismatched repair deficiency (dMMR) [9].

In the complex treatment decision-making algorithm, patient-related and/or tumorrelated characteristics should be taken into account $[10,11]$. Among patient-related features, clinicians should consider age, performance status, comorbidities, patients' preferences and values as well as life expectancy [12-14], while among tumor-related characteristics, primary tumor sidedness (i.e., right vs. left colon) [15-18] and molecular profile (i.e., KRAS-mutated vs. KRAS wild-type) [19,20] play a key (and growing) role. Currently, frontline chemotherapy regimens (i.e., the backbone of all available combinations) include leucovorin-modulated 5-fluorouracil, oxaliplatin, and irinotecan agents, which can be associated with monoclonal antibodies (MoAb) directed against the vascular endothelial 
growth factor (VEGF; bevacizumab) or the epidermal growth factor receptor (EGFR; panitumumab and cetuximab) [2,21]. RAS and BRAF are the two main genes involved in the EGFR intracellular signaling pathway and, to date, they are the only available biomarkers for aCRC that are routinely used in clinical practice [22,23]. RAS mutations, most frequently in exons 2, 3, and 4 of KRAS and NRAS as well as the mutually exclusive BRAF ones, lead to the constitutive activation of EGFR downstream transducers and bypasses the EGFR signaling blockade, with a consequent negative predictive role to anti-EGFR target therapy [24-32]. Moreover, the BRAF v600E mutation, which is most commonly located in right colon tumors, possesses a recognized unfavorable prognostic value [33-36]. As a consequence, the use of anti-EGFR agents, although limited to KRAS and BRAF wild type cancers, has contributed to greatly improving the outcome of patients harboring these alterations with a median overall survival (OS) reaching around 30 months $[37,38]$. However, the development of primary or secondary resistance is almost ineluctable. CRC, indeed, is a highly molecularly heterogeneous disease even in histologically comparable tumors and additional gene alterations frequently arise and accumulate, ultimately leading to disease progression under therapeutic pressure [39-43].

CRC biology and its genomic landscape has been extensively studied with the definition of four consensus molecular subtypes (CMSs) in 2015 [44] and the development of next-generation sequencing (NGS) techniques has advanced our understandings of CRC molecular profile [45]. In the commonly named PRESSING (primary resistance in RAS and BRAF wild-type mCRC patients treated with anti-EGFR monoclonal antibodies) panel, Cremolini and colleagues identified several uncommon genomic alterations, including HER2 amplification/activating mutations, MET amplification, ROS1/NTRK1-3/RET rearrangements, PIK3CA exon 20, PTEN, and ALK mutations. Among all of these gene alterations, the human epithelial growth factor receptor 2 (HER2) overexpression/amplification and, less frequently, mutations are the most common ones [46].

In this heterogeneous genomic scenario and in the era of precision medicine, despite the low prevalence of its genetic alterations, HER2 is emerging both as a key driver in CRC, as well as a predictor of benefits from novel targeted therapies [47]. This review aims at providing an overview of $H E R 2$ role in aCRC ranging from its predictive and prognostic relevance to its potential therapeutic implications as a new actionable oncotarget.

\section{The HER2 Pathway in Tumorigenesis}

\subsection{HER2 Pathway and Its Alterations in Solid Tumors}

The HER2/neu oncogene (also known as ErbB2 or p185), which is located on the long arm of human chromosome 17 (17q12), encodes a transmembrane glycoprotein receptor with intrinsic tyrosine kinase activity [48]. In contrast to other HER/EGFR/ERBB family members, HER2 is defined as an orphan receptor because of the lack of an endogenous ligand. Its activation depends on homodimerization or, most frequently, heterodimerization with other EGFR family receptors, in particular HER3 and EGFR, thus resulting in transphosphorylation of tyrosine residues within its cytoplasmic domain $[49,50]$. The downstream signal transduction pathways, including MAPK and PI3K/AKT/mTOR, results in cellular proliferation and differentiation, the inhibition of apoptosis, and tumor progression [51-55]. Notably, the HER2-HER3 heterodimers generate more potent stimulator signals than homodimers and particularly in initiating the PI3K/AKT pathway, which is one of the principal regulators of cell growth and survival [56,57] Figure 1. 


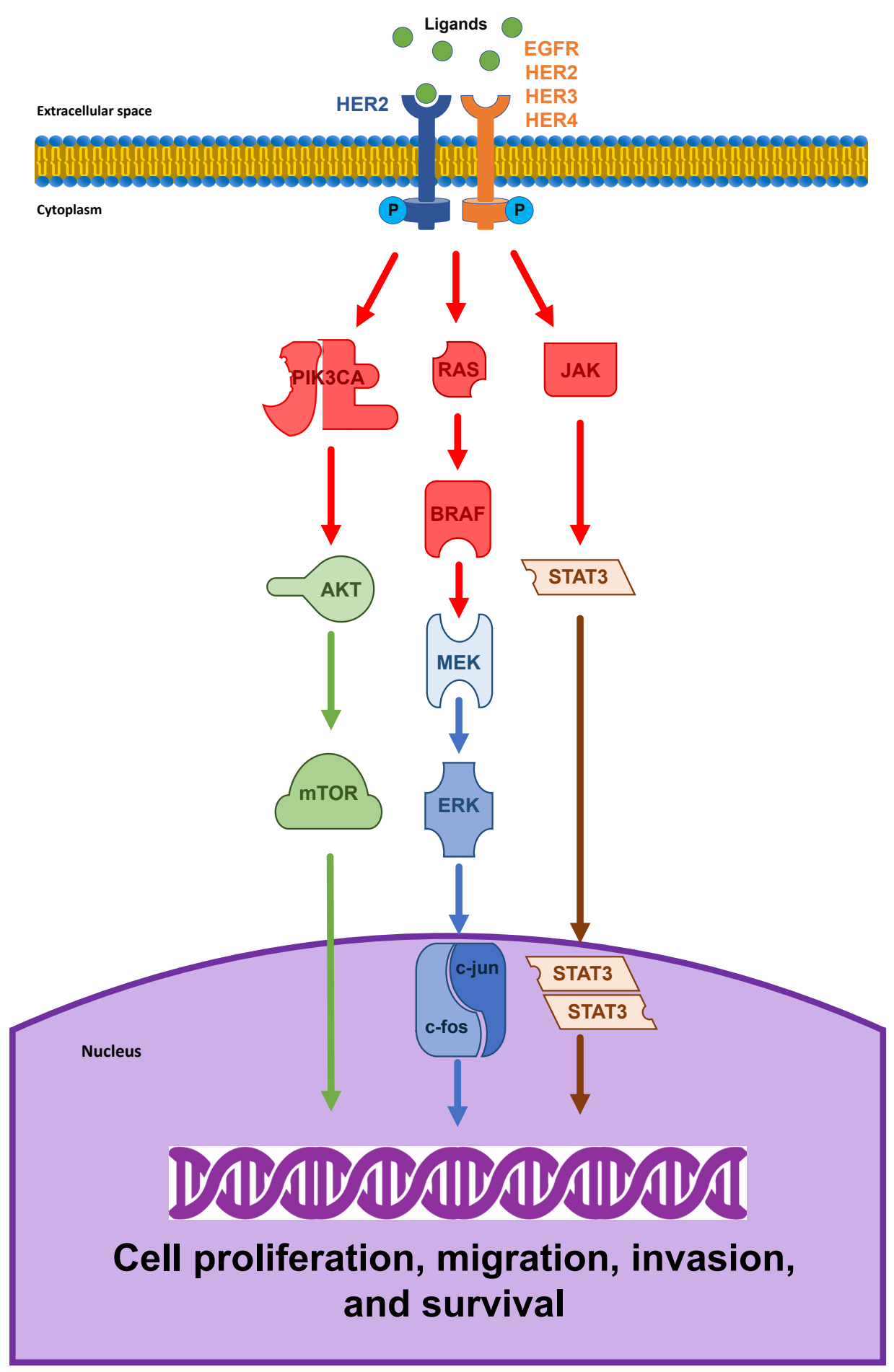

Figure 1. The HER2 pathway in tumorigenesis. Ligand binding to the extracellular domain of human epidermal growth factor receptor (HER2) stabilizes the dimerization between HER2 and another member of EGFR family receptors (EGFR, HER2, HER3, and HER4). By transphosphorylation of tyrosine residues within the cytoplasmic domains, the active homodimers or heterodimers thereafter stimulate several signaling cascades, such as the PI3K/AKT, the RAS/MAPK, and JAK/STAT pathways. These downstream pathways result in the transcription of genes driving tumor cell proliferation, migration, invasion, and survival.

The biological and clinical roles of HER2 activation have been well investigated in the pathogenesis of several malignancies [58,59] and it has been associated with aggressive tumor behavior, poor prognosis, and resistance to chemotherapy as well as with successful 
anti-HER2 targeted therapies, i.e., having both negative prognostic, as well as positive predictive value [60-66].

HER2 protein overexpression, usually (but not always) driven by gene amplification, was one of the earliest alterations identified in human cancers. Initially, HER2 oncogene amplification and/or HER2 receptor overexpression were recognized in up to $30 \%$ of breast cancers [67] and in many other tumor types, e.g., gastric, esophageal, lung, bladder, ovarian, endometrial, uterine cervix, head and neck, and colorectal cancers. In breast and gastroesophageal cancers, in particular, HER2 amplification distinguished a specific molecular subtype, with consolidated eligibility for anti-HER2 drugs [68-72]. On the other hand, in several tumors such as lung adenocarcinoma, urothelial, and salivary duct carcinoma, studies evaluating HER2 prognostic and therapeutic roles are still ongoing [73-75].

Additionally, in addition to HER2 amplification, somatic activating mutations within HER2 itself have recently been identified as drivers of tumorigenesis and had been observed first in non-small-cell lung cancer and then subsequently in a wide variety of cancers [76-82]. Heterogeneous HER2 mutations, indeed, have been discovered across all HER2 gene exons involving extracellular, transmembrane, or tyrosine kinase cytoplasmic domains, with the consequent activation of downstream signaling pathways even in the presence of a normal gene copy number [83].

\subsection{HER2 Alterations in aCRC}

Although observed less frequently than in other malignancies and also in colorectal adenocarcinoma, HER2 amplification or somatic mutations have been described in the past two decades, with highly different reported rates of positivity (from $<1 \%$ to $>50 \%$ ) [84-91]. This variability, particularly in HER2 amplification prevalence, may be due to several factors, including cohort heterogeneity and a small study population, antibody clone selection, staining platform, and different scoring systems [86]. For example, higher rates of HER2 positivity were observed in studies assessing not only membranous but also (and above all) cytoplasmic HER2 overexpression [89]. However, cytoplasmic evaluation has an uncertain biological relevance in CRC as well as in breast and gastric cancers, with no recognized role in standard scoring methodologies because of a possible overestimation of true HER2 positivity [91]. Typically, HER2+ CRC cells present a strong lateral membrane staining, while basal membrane staining is not always observed [92]. The Cancer Genome Atlas (TCGA) project detected HER2 alterations in around 7\% of patients affected by CRC, especially in RAS and BRAF wild-type tumors [93]. Although controversial, HER2 overexpression has been observed more frequently in high tumor mutational burden and advanced $\mathrm{T}$ stage [86], while some studies evidenced a significant discordance between primary tumors and metastases, suggesting the loss of HER2 positivity during disease progression [94,95]. Moreover, HER2 status has been related to sidedness and, more frequently, HER2-amplified primary tumors have been located in the rectum, as well as in the left colon [96-98]. As far as HER2 somatic mutations, they have been reported by TCGA project data in about $4 \%$ of CRC and sometimes concomitantly with HER 2 amplification or alterations of other oncogenes such as RAS, BRAF, and EGFR. Recently, HER2 activating mutations have also been associated with MSI-H tumors [99]. According to Kavuri and colleagues, these mutations, which are often the same ones identified in breast cancer, include V842I, S3210F, L755S, V777L, and L866M [100]. Additionally, in the PRESSING panel another single HER2 mutation, i.e., the substitution G776V on exon 20, was found [46].

\section{HER2 Status Characterization in aCRC}

Unlike breast and gastric cancers, a specific scoring system for defining HER2 positivity in CRC was not been completely established until the introduction of the HERACLES (HER2 Amplification for Colorectal Cancer Enhanced Stratification) criteria. In 2016, Valtorta and colleagues developed and validated the first diagnostic algorithm for HER2 in CRC during the enrollment for the HERACLES study, which is a phase II trial evaluating the combination of two anti-HER2 monoclonal antibodies (trastuzumab and lapatinib) in 
KRAS wild-type metastatic CRC patients refractory to standard treatment. These criteria, which are similar but more stringent than the accepted and routinely used ones in breast and gastric cancers, are based on the standard methodologies for the assessment of HER2 protein overexpression and gene amplification and are represented by immunochemistry (IHC) and fluorescent or silver in situ hybridization (FISH or SISH), respectively.

According to Valtorta and colleagues, HER2 positivity is defined as 3+ IHC score (intense expression) in more than $50 \%$ of tumor cells or $3+$ IHC score in $10-50 \%$ of the tumor cells and further FISH confirmation by HER2: CEP17 (chromosome enumeration probe) ratio $\geq 2$ in more than $50 \%$ of tumor cells or $2+$ IHC score (moderate expression) in more than $50 \%$ of tumor cells associated with a FISH positive evaluation. Notably, only membranous HER2 expression in its lateral, basolateral, or circumferential patterns counts toward positivity $[92,101,102]$.

However, other studies applied the HER2 diagnostic criteria proposed by Ruschoff and colleagues in gastroesophageal adenocarcinoma (GEA criteria) and also in CRC $[87,89,103,104]$. The main difference from the HERACLES criteria consists of the cutoff value for IHC definition. In the GEA criteria, indeed, HER2 positive tumors are those possessing an IHC score of $3+$ in more than $10 \%$ of tumor cells or an IHC score of $2+$ in more than $10 \%$ of tumor cells with confirmed HER2 gene amplification by FISH.

Liu and colleagues compared these two different scoring systems in a large cohort of Chinese CRC patients, demonstrating a very high rate of concordance between them despite HER2's particularly low prevalence in this population (2.9\% according to the GEA criteria versus $2.6 \%$ according to the HERACLES criteria) $[105,106]$ (Table 1).

Table 1. The HER2-positivity definition in aCRC according two different system: the HERACLES criteria and the GEA criteria.

HER2 Positivity in aCRC

- $\quad 3+\mathrm{IHC}$ score * in more than $50 \%$ of the tumor cells; OR

- $3+$ IHC score in 10 50\% of the tumor cells and FISH positive; OR

- $2+$ IHC score ${ }^{* *}$ in more than $50 \%$ of the tumor cells by IHC and FISH positivity ***.
- $\quad 3+$ IHC score in more than $10 \%$ of the tumor cells; OR

- $2+$ IHC score in more than $10 \%$ of the tumor cells and FISH positivity*.

HER2: Human epidermal growth factor receptor 2; HERACLES: HER2 Amplification for Colorectal Cancer Enhanced Stratification; GEA: gastroesophageal adenocarcinoma; IHC: immunochemistry; FISH: fluorescent in situ hybridization. * 3+ IHC score is represented by an intense and strong lateral, basolateral, or circumferential membranous HER2 expression. ** 2+ IHC score is represented by a moderate lateral, basolateral, or circumferential membranous HER2 expression. ${ }^{* * *}$ FISH positivity is defined as a HER2:CEP17 (chromosome enumeration probe) ratio $\geq 2$.

Additional approaches to detect HER2 gene amplification, as well as its activating mutations in CRC, include molecular techniques such as next-generation sequencing (NGS) or comprehensive genomic sequencing (CGS). Both of these techniques, which involve profiling the DNA extracted from formalin-fixed and paraffin-embedded (FFPE) tumor samples, allow the identification of HER2 copy number and/or sequence alterations. The strong concordance with gold standard methods (IHC and FISH) across different tumor types supports their application in CRC $[107,108]$. In the MyPathway phase II basket trial, the efficacy of the two anti-HER2 agents, pertuzumab and trastuzumab, in patients with refractory metastatic HER2 positive CRC and HER2 status have been evaluated not only by IHC and FISH but also by NGS [109].

Recently, an international project among three groups (GI-SCREEN-Japan, NCTNSWOG-USA, and Korea) aimed at harmonizing the diagnostic criteria for HER2 in metastatic CRC by matching IHC, FISH, and NGS data was launched. Based on several clinical trials testing HER2-targeted therapy, Fujii and colleagues integrated the results of HER2 assessment by IHC/FISH with NGS evaluation across different platforms. After demonstrating the accuracy of IHC/FISH scoring systems and cross-validation of NGS panels, the authors 
proposed new harmonized HER2 diagnostic criteria in CRC as follows: IHC 3+ score or IHC2+ score associated with HER2: CEP17 ratio $>$ or $=2$ by FISH in more than $10 \%$ of tumor cells for surgically resected samples. In the balance of the risk-versus-benefit ratio, the cutoff of $10 \%$ for tumor content had been accepted to allow patient registration in the clinical trials of each country. However, in the efforts to distinguish patients who really would benefit from anti-HER2 agents, they emphasized the importance of performing HER2 assessment on surgical specimens rather than on biopsy ones in order to avoid HER2 false positivity due to HER2 heterogeneous expression in CRC cells [110]. Although this study needs to be validated within a prospective clinical trial, it revealed the opportunity for formulating an international and integrated HER2 diagnostic criteria in CRC, using NGS as a bridge between the two gold methods IHC and FISH. A previous study, conducted by Shimada and colleagues showed that CGS has the same sensitivity as IHC and FISH for recognizing HER2 positive CRC patients who are candidates for anti-HER2 targeted therapy [108]. As a consequence, thanks to its reproducibility and ability to detect gene mutations and copy number variations in a single assay, CGS can potentially facilitate tailor-made treatments.

Moreover, the use of the emerging liquid biopsy even to identify HER2 status in CRC from circulating tumor DNA (ctDNA) represents an attractive future diagnostic tool [111-113], but it requires further investigations.

\section{HER2 Predictive Role to EGFR-Targeted Therapy in aCRC}

Since 2011, HER2 alterations have been proposed as a mechanism for both de novo and acquired resistance to EGFR-targeted therapies in aCRC. The first proof of the HER2 role as a potential negative biomarker of response to anti-EGFR agents derived from preclinical data in colon cancer cell lines and xenograft models. In a large platform of patient-derived tumor xenografts (PDTX), Bertotti and colleagues showed a significantly higher prevalence of HER2 gene amplification in cetuximab-resistant RAS, BRAF, and PIK3CA wild-type tumors [114]. Yonesaka and colleagues also investigated the predictive impact of HER2 amplification in metastatic CRC cetuximab-resistant cell lines in vitro and in vivo [115]. These authors demonstrated that HER2 activation, either through HER2 amplification or the HER3-activating ligand heregulin upregulation, results in persistent ERK1/2 signaling and results in anti-EGFR resistance. In addition, the subsequent inhibition of HER2 overexpression by a small interfering RNA, as well as the disruption of the HER2/HER3 heterodimerization by depletion of heregulin, restores sensitivity to cetuximab. Consistent with preclinical observations, they extended these findings in a cohort of 233 cetuximabtreated CRC patients, demonstrating a shorter PFS and OS in those patients with HER2amplified tumors and higher serum heregulin levels. Furthermore, Mohan et al. detected HER2 amplification in tumors or ctDNA of CRC patients that are non-responding to antiEGFR MoAb [116]. In the effort to clinically validate HER2 negative impacts on the efficacy of anti-EGFR therapies, other retrospective analyses confirmed the results of Yonesaka and colleagues, evidencing a significantly worse median PFS and OS in patients with HER2 amplification compared with the non-amplification group [117-119]. In particular, as suggested by previous preclinical data, Sawada and colleagues revealed that the PFS of HER2-amplificated mCRC treated with anti-EGFR targeted therapy was not only poorer than that of the wild-type RAS/BRAF but also similar to that of patients harboring RAS mutations [118]. In the HERACLES-A study, the OS between patients with HER2-positive $\mathrm{CRC}$ and the control cohort was not significantly different. However, the authors of the study reported a lower objective response rate (ORR) to anti-EGFR therapies in HER2amplified CRC patients and relied on a strong biological rationale, as HER2 overexpression represents an alternative pathway to obviate EGFR signaling in tumorigenesis and/or in tumor progression [101,120].

Similarly, HER2 somatic mutations have also been implicated in the resistance to antiEGFR agents. Within the frame of the HERACLES project as well as in the PRESSING panel 
created by Morano and colleagues, the investigators uncovered HER2 activating mutations as an intrinsic predictor of non-responsiveness to the anti-EGFR therapies [101,121].

In the recent past, Pietrantronio and colleagues conducted the first small prospective study to clarify the mechanisms of acquired resistance to anti-EGFR MoAb in mCRC patients. Analyzing both tissue and liquid biopsy samples, the authors illustrated the complex landscape of CRC molecular heterogeneity and detected HER2 amplification within the different and often co-occurrent mechanisms driving secondary resistance to EGFR blockade and converging on MAPK pathway reactivation [122]. Even if currently available data require further validation in larger prospective trials, they all strongly suggest that HER2 represents a relevant molecular predictive biomarker for anti-EGFR therapies in CRC.

\section{HER2 Prognostic Role in aCRC}

In contrast to the higher recognized predictive role for anti-EGFR targeted therapies, HER2 prognostic significance in aCRC is still uncertain. Although early studies [123,124], which are those that considered the cytoplasmic expression of HER2 as a criterion for positivity, reported worse outcomes, the more recent trials [87,118,125-127] that only evaluated membranous HER2 expression have not demonstrated a clear correlation with prognosis. In a pooled analysis from three clinical trials (QUASAR, FOCUS, and PICCOLO), Richman SD and colleagues did not find a statistically significant association between HER2 expression and OS [87]. However, Ingold Heppner B and colleagues, in one of the largest cohorts of CRC (from all CRC stages), identified a trend towards a lower OS in patients with HER2-amplified CRC [86]. Subsequently, in another study, which is the the PETACC-8 trial that included exclusively stage III CRC patients treated with adjuvant FOLFOX, revealed an association of HER2 alterations possessing shorter time to recurrence and OS, even after adjustments for multiple clinical and pathological factors [128]. The potential prognostic impact of HER2 is probably hindered by its relatively low incidence in CRC, even if a meta-analysis of 18 studies with 2867 CRC patients confirmed HER2 as an insignificant predictor of survival [129]. Recently, Khelwatty and colleagues evaluated how EGFR and membranous HER2 co-expression impact the outcome of cetuximab-treated patients with mCRC and shoed that when HER2 and EGFR are localized on the cell wall, a shorter PFS is observed [130].

However, even in evaluating the inconsistent results to date available, the HER2 prognostic role remains controversial and its negative effect on OS in CRC, if any, is probably less relevant, than compared with other molecular alterations, e.g., BRAF v600E.

\section{Anti-HER2 Therapeutic Strategies in aCRC}

\subsection{Preclinical Investigations and Clinical Evidence on HER2 Therapeutic Role in aCRC}

Based on the success of routinely used HER2 targeting agents in breast and gastric malignancies, preclinical investigations tested the potential therapeutic role of HER2 in aCRC. A proof-of-concept was derived from HER2-amplified cetuximab-resistant CRC xenograft models where the dual EGFR/HER2 inhibition generated long-lasting tumor regression [114]. In particular, while the anti-HER2 agent pertuzumab, when given alone or in association with cetuximab, induced only a negligible delay in tumor growth, the combination of lapatinib (a dual EGFR/HER2 tyrosine kinase inhibitor) and pertuzumab or, at a lesser extent, of lapatinib and cetuximab caused a significant and durable tumor shrinkage. Similarly, in cetuximab-resistant CRC cell lines, the synergic antiproliferative effect of the anti-HER2 and anti-EGFR agent combinations (e.g., trastuzumab plus lapatinib or trastuzumab plus cetuximab) was demonstrated $[115,131,132]$. Preclinical findings also showed that the growth of colon cell lines harboring HER2 activating mutations could be potently inhibited by the irreversible tyrosine kinase inhibitors (TKI) neratinib and afatinib. Moreover, in HER2-mutated PDTXs, an anti-HER2 monotherapy (with either trastuzumab, neratinib, or lapatinib) delayed tumor growth, whereas a dual anti-HER2 strategy (with either trastuzumab plus neratinib or trastuzumab plus lapatinib) produced durable tumor 
regression [100]. According to Kloth and colleagues, activating HER2 mutations also indicates the susceptibility to pan-HER2 irreversible inhibitors in Lynch and Lynch-like HER2 mutated CRC cell lines [133].

All these preclinical data built a solid background and a strong rationale for clinical trials targeting HER2 alterations in patients with aCRC and paved the way for the HERACLES project. During the last decade, several small studies assessed HER2 as a therapeutic target in combination with standard chemotherapies or anti-EGFR drugs. The early clinical studies evaluating the association of anti-HER2 MoAb (i.e., trastuzumab and pertuzumab) and cetuximab or cytotoxic agents (i.e., irinotecan, fluorouracil, and oxaliplatin) were prematurely shut down because of the severe overlapping toxicities [134] or poor accrual $[135,136]$. Subsequently, in a phase I basket trials including patients with HER2-positive refractory solid tumors, none of six CRC patients experienced an objective response to the combination of paclitaxel, interleukin-12, and trastuzumab [137] and only two of the eight CRC patients had a partial response to the association of cetuximab and lapatinib while in the absence of complete tumor regression [138]. However, the small sample size and the design of these studies probably did not allow the recognition of the contribution of anti-HER2 agents to tumor response.

More recently, preclinical observations [114] supported the clinical investigation of "chemotherapy-free" regimens based on the combination of HER2-targeted drugs. The HERACLES-A (HER2 Amplification for Colo-Rectal Cancer Enhanced Stratification) was the first large phase II clinical trial testing weekly trastuzumab plus daily lapatinib in HER2 positive KRAS exon 2 wild type aCRC patients who proved to be refractory to standard-of-care therapy, including cetuximab. Sartore-Bianchi and colleagues presented the promising results of this pivotal study after the screening of 914 patients according to the stringent HERACLES Criteria. Enrolling 27 HER2-positive eligible patients in the study, the authors reported an objective response rate of $30 \%$, with a median duration of response being 9.5 months and a median PFS of 5.2 months [101]. This response rate, together with the good overall toxicity profile of the treatment (no grade- 4 or grade- 5 adverse events), compared favorably with other treatment options in heavily pretreated $\mathrm{mCRC}$ patients. In line with the HERACLES-A results, the MyPathway phase IIa basket trial, by assessing the association of pertuzumab and trastuzumab in pretreated HER2-amplified mCRC patients, further supports the activity of dual HER2 blockade strategy $[139,140]$. The updated report of the study, indeed, showed an overall response rate (ORR) of 32\% in this cohort of patients, with a median PFS and OS of 2.9 and 11.5 months, respectively. Although, unlike HERACLES, the MyPathway study KRAS status was not evaluated as a criterion of eligibility, the ORR was much higher in the KRAS wild-type mCRC tumors and reached $42 \%$, whereas the efficacy of the pertuzumab/trastuzumab combination was not demonstrated in KRAS-mutated ones and had an ORR of 8\% [60]. Interestingly, both the HERACLES-A and MyPathway studies evidenced a significant correlation between a high HER2 gene copy number and a longer PFS from the dual blockade. Moreover, in an exploratory data analysis of HERACLES-A, Siravegna and colleagues proposed a specific plasmatic HER2 copy number to select patients who would really benefit from HER2-targeted therapies [141]. Within the HERACLES project, the HERACLES-B trial also investigated the efficacy of pertuzumab in association with the antibody-drug conjugate trastuzumab-emtansine (T-DM1) in the same subset of patients. Even if the study did not reach its primary endpoint of ORR, the high disease control rate, which is about $68 \%$, the PFS similar to other anti-HER2 regimens, and the safety profile supports the dual anti-HER2 blockade as a potential therapeutic resource for HER2+ mCRC [142].

\subsection{Ongoing Trials on Anti-HER2 Targeted Therapies in aCRC}

Thanks to the encouraging results of phase II studies including HERACLES and MyPathway, many trials testing several anti-HER2 drugs are currently in progress and available preliminary data show that various therapeutic approaches could be active in HER2-positive mCRC patients. Among different new HER2-related strategies in develop- 
ment, a boosted interest is related to HER2-targeted antibody-drug conjugates (i.e., TDM-1, DS-8201, A166, ZW25, and ZW49), novel TKIs (i.e., tucatinib, sapitinib, neratinib, pyrotinib and poziotinib, and Ceralasertib), and HER2-targeted immunotherapy (i.e., vaccines, donor-derived NK cells, and CAR-T cells) (Figure 2). Moreover, preclinical investigations suggested that combination strategies, including the concomitant inhibition of HER2 and other oncotargets (such as PI3K and MEK), are able to induce colorectal cancer stem cell death, leading to cancer regression in xenograft models [143].

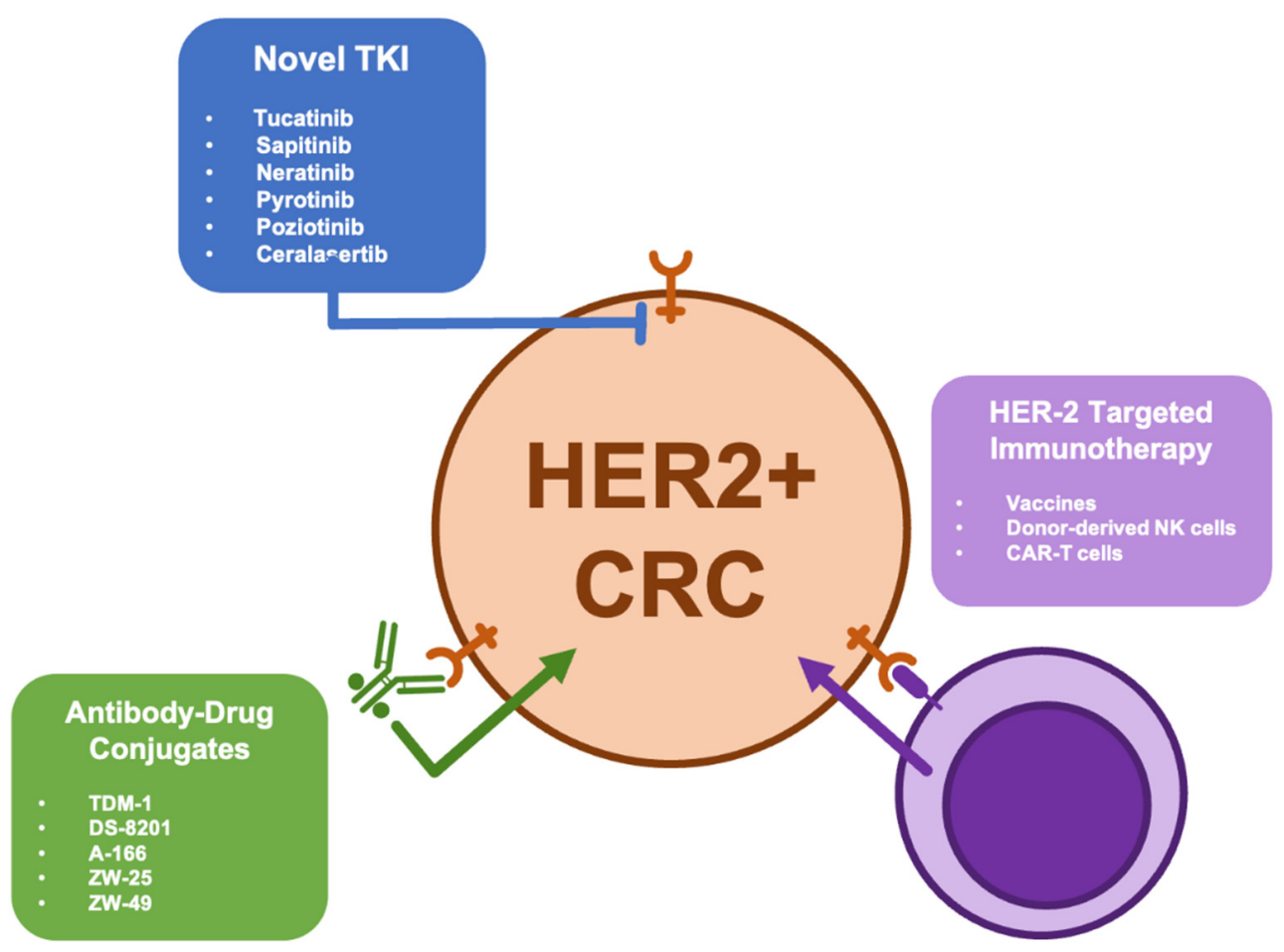

Figure 2. Novel therapeutic strategies for HER-2 positive colorectal cancer.

Recently, Siena and Coll. published the results of the DESTINY-CRC01 phase II study which shows promising and durable activity of trastuzumab deruxtecan (DS-8201) in patients with refractory HER2-positive mCRC; notably, this activity was evident even in those patients who had previously received HER2-targeted therapies. In particular, in cohort A (including HER2 IHC 3+ or IHC2+ and ISH-positive mCRC patients), the authors documented the regression of target lesions, as well as lasting responses; this ultimately resulted in PFS and OS benefits [144]. Table 2 describes the main features of the principal ongoing trials on HER2 in aCRC (Table 2). 
Table 2. Ongoing currently trials in HER2-positive aCRC patients (clinicalTrials.gov Search Results 05/27/2021; key words: colorectal cancer, HER2).

\begin{tabular}{|c|c|c|c|}
\hline Title of the Study/NCT & Status/Phase & Intervention & Primary-Outcome Measures \\
\hline $\begin{array}{l}\text { 1. A Study of Pyrotinib Combined with Capecitabine for } \\
\text { Metastatic HER-2 Positive Colorectal Cancer/NCT04227041 }\end{array}$ & Not yet recruiting/Phase I-II & $\begin{array}{l}\text { - Drug: Pyrotinib in combination with } \\
\text { capecitabine }\end{array}$ & MTD; PFS \\
\hline $\begin{array}{l}\text { 2. A Clinical Study of Pyrotinib in Patients of Advanced } \\
\text { Colorectal Cancer with Her2 Variation/NCT04380012 }\end{array}$ & Recruiting/Phase II & $\begin{array}{l}\text { - } \quad \text { Drug: Pyrotinib } \\
\text { Drug: Pyrotinib in combination with } \\
\text { trastuzumab }\end{array}$ & ORR \\
\hline $\begin{array}{l}\text { 3. Study of Neratinib + Trastuzumab or Neratinib + } \\
\text { Cetuximab in Patients with KRAS/NRAS/BRAF/PIK3CA } \\
\text { Wild-Type Metastatic Colorectal Cancer by HER2 } \\
\text { Status/NCT03457896 }\end{array}$ & Recruiting/Phase II & $\begin{array}{l}-\quad \text { Drug: Trastuzumab; } \\
\text { - } \quad \text { Drug: Cetuximab } \\
\text { - } \quad \text { Drug: Neratinib } \\
\text { Diagnostic Test: Guardant360 }\end{array}$ & PFS \\
\hline $\begin{array}{l}\text { 4. Trastuzumab Deruxtecan in Participants with } \\
\text { HER2-overexpressing Advanced or Metastatic Colorectal } \\
\text { Cancer/NCT04744831 }\end{array}$ & Not yet recruiting/Phase II & $\begin{array}{l}\text { - } \quad \text { Drug: DS-8201a } 5.4 \mathrm{mg} / \mathrm{kg} \text { Q3W } \\
\text { - } \quad \text { Drug: DS-8201a } 6.4 \mathrm{mg} / \mathrm{kg} \text { Q3W }\end{array}$ & ORR \\
\hline $\begin{array}{l}\text { 6. Pyrotinib in Combination with Trastuzumab in } \\
\text { Treatment- Refractory, HER2-positive Metastatic } \\
\text { Colorectal Cancer/NCT03843749 }\end{array}$ & Recruiting/Not Applicable & - Drug: Pyrotinib & ORR \\
\hline $\begin{array}{l}\text { 7. Evaluation of Trastuzumab in Combination with } \\
\text { Lapatinib or Pertuzumab in Combination with } \\
\text { Trastuzumab-Emtansine to Treat Patients with } \\
\text { HER2-positive Metastatic Colorectal Cancer } \\
\text { (HERACLES)/NCT03225937 }\end{array}$ & Unknown status/Phase II & $\begin{array}{l}\text { - } \quad \text { Drug: Trastuzumab, Lapatinib } \\
\text { - } \quad \text { Drug: Pertuzumab, trastuzumab-emtansine }\end{array}$ & ORR \\
\hline $\begin{array}{l}\text { 8. Monoclonal Antibody Plus Chemotherapy in Treating } \\
\text { Patients with Advanced Colorectal Cancer That } \\
\text { Overexpresses HER2/NCT00003995 }\end{array}$ & Completed/Phase II & $\begin{array}{l}\text { - } \quad \text { Biological: trastuzumab } \\
\text { - } \quad \text { Drug: irinotecan hydrochloride }\end{array}$ & ORR \\
\hline
\end{tabular}


Table 2. Cont.

\begin{tabular}{|c|c|c|c|}
\hline Title of the Study/NCT & Status/Phase & Intervention & Primary-Outcome Measures \\
\hline $\begin{array}{l}\text { 9. Tucatinib Plus Trastuzumab in Patients with HER2+ } \\
\text { Colorectal Cancer (MOUNTAINEER)/NCT03043313 }\end{array}$ & Recruiting/Phase II & $\begin{array}{l}\text { - } \quad \text { Drug: Trastuzumab } \\
\text { - } \quad \text { Drug: Tucatinib }\end{array}$ & cORR \\
\hline $\begin{array}{l}\text { 10. A Phase } 1 \text { Study of SHR-A1811 in Patients with } \\
\text { Selected HER2 Expressing Tumors/NCT0 } 4513223\end{array}$ & Not yet recruiting/Phase I & - $\quad$ Drug: SHR-A1811 & DLT; RP2D \\
\hline $\begin{array}{l}\text { 11. S1613, Trastuzumab and Pertuzumab or Cetuximab } \\
\text { and Irinotecan Hydrochloride in Treating Patients with } \\
\text { Locally Advanced or Metastatic HER2/Neu Amplified } \\
\text { Colorectal Cancer That Cannot Be Removed by } \\
\text { Surgery/NCT03365882 }\end{array}$ & Recruiting/Phase II & $\begin{array}{ll}\text { - } & \text { Biological: Cetuximab } \\
\text { - } & \text { Drug: Irinotecan Hydrochloride } \\
\text { - } & \text { Other: Laboratory Biomarker Analysis } \\
\text { - } & \text { Biological: Pertuzumab, Trastuzumab } \\
\text { - } & \text { Device: HER-2 testing }\end{array}$ & PFS \\
\hline $\begin{array}{l}\text { 12. Vaccine Therapy in Treating Patients with Stage IIB, } \\
\text { Stage III, or Stage IV Colorectal Cancer/NCT00091286 }\end{array}$ & Terminated/Early Phase I & $\begin{array}{l}\text { - Biological: HER-2-neu, CEA peptides, GM- } \\
\text { CSF, Montanide ISA-51 vaccine }\end{array}$ & Safety \\
\hline $\begin{array}{l}\text { 14. A Study of Poziotinib in Patients with EGFR or HER2 } \\
\text { Activating Mutations in Advanced } \\
\text { Malignancies/NCT04172597 }\end{array}$ & Recruiting/Phase II & - $\quad$ Drug: Poziotinib Hydrochloride & ORR \\
\hline $\begin{array}{l}\text { 15. Safety and Preliminary Efficacy of SNK01 in } \\
\text { Combination with Trastuzumab or Cetuximab in Subjects } \\
\text { with Advanced HER2 or EGFR Cancers/NCT04464967 }\end{array}$ & Not yet recruiting/Phase I-II & $\begin{array}{l}\text { - } \quad \text { Biological: SNK01 } \\
\text { - } \quad \text { Drug: Trastuzumab, Cetuximab }\end{array}$ & RP2D; ORR \\
\hline $\begin{array}{l}\text { 16. A Clinical Research of CAR T Cells Targeting HER2 } \\
\text { Positive Cancer/NCT02713984 }\end{array}$ & Withdrawn/Phase I-II & - Biological: Anti-HER2 CAR-T & CTCAE \\
\hline $\begin{array}{l}\text { 17. Testing the Combination of Two Anti-cancer Drugs, } \\
\text { DS-8201a and AZD6738, for the Treatment of Patients } \\
\text { With Advanced Solid Tumors Expressing the HER2 } \\
\text { Protein or Gene, the DASH trial/NCT04704661 }\end{array}$ & Not yet recruiting/Phase I & $\begin{array}{l}\text { - } \quad \text { Drug: Ceralasertib } \\
\text { - } \quad \text { Biological: Trastuzumab Deruxtecan }\end{array}$ & $\begin{array}{l}\text { AEs (For Escalation Phase); } \\
\text { RP2D }\end{array}$ \\
\hline
\end{tabular}


Table 2. Cont

\begin{tabular}{|c|c|c|c|}
\hline Title of the Study/NCT & Status/Phase & Intervention & Primary-Outcome Measures \\
\hline $\begin{array}{l}\text { 18. Tucatinib Plus Trastuzumab and Oxaliplatin-based } \\
\text { Chemotherapy for HER2+ Gastrointestinal } \\
\text { Cancers/NCT04430738 }\end{array}$ & Recruiting/Phase I-II & $\begin{array}{ll}\text { - } & \text { Drug: tucatinib } \\
\text { - } & \text { Drug: trastuzumab } \\
\text { - } & \text { Drug: oxaliplatin } \\
\text { - } & \text { Drug: leucovorin } \\
\text { - } & \text { Drug: fluorouracil } \\
\text { - } & \text { Drug: capecitabine }\end{array}$ & $\begin{array}{l}\text { Renal dose-limiting toxicities; } \\
\text { AEs; laboratory abnormalities. }\end{array}$ \\
\hline $\begin{array}{l}\text { 20. CAR-macrophages for the Treatment of HER2 } \\
\text { Overexpressing Solid Tumors/NCT04660929 }\end{array}$ & Recruiting/Phase I & - Biological: CT-0508 & Safety and tolerability. \\
\hline $\begin{array}{l}\text { 21. Study of A166 in Patients with Relapsed/Refractory } \\
\text { Cancers Expressing HER2 Antigen or Having Amplified } \\
\text { HER2 Gene/NCT03602079 }\end{array}$ & Recruiting/Phase I-II & - $\quad$ Drug: A166 & MTD \\
\hline
\end{tabular}

\section{Phase I/II Trial of Antagonism of HER in GI Cancer/NCT04246671}

Completed/Phase I-II
- Drug: AZD8931

- Drug: Irinotecan

- Drug: Folinic Acid

- Drug: Fluorouracil
24. Lapatinib and Cetuximab in Patients with Solid Tumors/NCT01184482

25. FATE-NK100 as Monotherapy and in Combination with Monoclonal Antibody in Subjects with Advanced Solid Tumors/NCT03319459
Completed/Phase I

- Drug: cetuximab, lapatinib

- Drug: FATE-NK100

- Drug: Cetuximab

- Drug: Trastuzumab

MTD

Active, not recruiting/Phase I
ORR 
Table 2. Cont.

\begin{tabular}{|c|c|c|c|}
\hline Title of the Study/NCT & Status/Phase & Intervention & Primary-Outcome Measures \\
\hline $\begin{array}{l}\text { 26. A Study of SBT } 6050 \text { Alone and in Combination with } \\
\text { Pembrolizumab in Patients with Advanced HER2 } \\
\text { Expressing Solid Tumors/NCT04460456 }\end{array}$ & Recruiting/Phase I & $\begin{array}{l}\text { - } \quad \text { Drug: SBT6050 } \\
\text { - Drug: pembrolizumab }\end{array}$ & DLT; AEs \\
\hline $\begin{array}{l}\text { 27. A Dose Finding Study of ZW49 in Patients with } \\
\text { HER2-Positive Cancers/NCT03821233 }\end{array}$ & Recruiting/Phase I & - $\quad$ Drug: ZW49 & DLT; AEs \\
\hline $\begin{array}{l}\text { 28. ACE1702 in Subjects with Advanced or Metastatic } \\
\text { HER2- expressing Solid Tumors/NCT04319757 }\end{array}$ & Recruiting/Phase I & $\begin{array}{ll}- & \text { Drug: ACE1702 } \\
\text { - } & \text { Drug: Cyclophosphamide } \\
\text { - } & \text { Drug: Fludarabine }\end{array}$ & DLT; SAEs; MTD \\
\hline $\begin{array}{l}\text { 29. A Safety and Efficacy Study of ZW25 (Zanidatamab) } \\
\text { Plus Combination Chemotherapy in HER2-expressing } \\
\text { Gastrointestinal Cancers, Including Gastroesophageal } \\
\text { Adenocarcinoma, Biliary Tract Cancer, and Colorectal } \\
\text { Cancer/NCT03929666 }\end{array}$ & Recruiting/Phase II & $\begin{array}{ll}\text { - } & \text { Drug: ZW25 (Zanidatamab) } \\
\text { - } & \text { Drug: Capecitabine } \\
\text { - } & \text { Drug: Cisplatin } \\
\text { - } & \text { Drug: Fluorouracil } \\
\text { - } & \text { Drug: Leucovorin } \\
\text { - } & \text { Drug: Oxaliplatin } \\
\text { - } & \text { Drug: Bevacizumab } \\
\text { - } & \text { Drug: Gemcitabine }\end{array}$ & $\begin{array}{l}\text { DLT; CTCAE; } \\
\text { ORR }\end{array}$ \\
\hline $\begin{array}{l}\text { 30. A First-in-human Study Using BDC-1001 in Advanced } \\
\text { HER2-Expressing Solid Tumors/NCT04278144 }\end{array}$ & Recruiting/Phase I-II & $\begin{array}{ll}- & \text { Drug: BDC-1001 } \\
- & \text { Drug: Pembrolizumab }\end{array}$ & SAEs; DLT; MTD; ORR \\
\hline $\begin{array}{l}\text { 31. Study of Bosutinib With Capecitabine In Solid Tumors } \\
\text { And Locally Advanced Or Metastatic Breast } \\
\text { Cancer/NCT00959946 }\end{array}$ & Terminated/Phase I-II & $\begin{array}{l}-\quad \text { Drug: Bosutinib } \\
\text { - } \quad \text { Drug: Capecitabine }\end{array}$ & MTD; SAEs; ORR \\
\hline $\begin{array}{l}\text { 32. Pembrolizumab and Monoclonal Antibody Therapy in } \\
\text { Advanced Cancer/NCT02318901 }\end{array}$ & Terminated/Phase I-II & $\begin{array}{ll}\text { - } & \text { Drug: Pembrolizumab } \\
\text { - } & \text { Drug: Trastuzumab } \\
\text { - } & \text { Drug: ado-trastuzumab emtansine } \\
\text { - } & \text { Drug: Cetuximab }\end{array}$ & $\mathrm{RP} 2 \mathrm{D}$ \\
\hline
\end{tabular}


Table 2. Cont.

Title of the Study/NCT

33. Targeted Agent Evaluation in Digestive Cancers in China Based on Molecular Characteristics

(VISIONARY)/NCT04584008

Recruiting/Not Applicable
Intervention

Primary-Outcome Measures

- Drug: FGFR Inhibitor, IDH1 Inhibitor, HER2

Inhibitor, PARP Inhibitor, BRAF Inhibitor,

MEK Inhibitor, ICIs, EGFR-TKIs, NTRK-

ORR

TKI, and etc.

- Drug: Other Therapy

\section{A Study of T-DXd for the Treatment of Solid Tumors}

Harboring HER2 Activating Mutations

(DPT01)/NCT04639219

35. A Study of BDTX-189, an Orally Available Allosteric ErbB Inhibitor, in Patients with Advanced Solid Tumors (MasterKey-01)/NCT04209465

\section{A Study of SGN-CD228A in Advanced Solid} Tumors/NCT04042480
Recruiting/Phase II

Recruiting/Phase I-II

Recruiting/Phase I
- Drug: Trastuzumab deruxtecan

- $\quad$ Drug: BDTX-189

RP2D; ORR

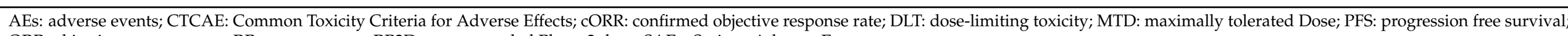
ORR: objective response rate; RR: response rate; RP2D: recommended Phase 2 dose; SAEs: Serious Adverse Events.

- $\quad$ Drug: SGN-CD228A

MTD; SAEs; ORR 


\section{Future Perspectives and Conclusions}

Despite the improvements in the systemic treatment of aCRC made in the past two decades, to date CRC does not have specific oncotargets beyond RAS and BRAF. However, because of its histological heterogeneity and its genetic dynamic evolution during disease progression and under therapeutic pressure, CRC could represent one of the most fertile grounds for the development of precision oncology and approach. In this context, the identification of novel clinically actionable oncogenic drivers expresses an unsatisfied and urgent need. Although, unlike other malignancies, HER2 alterations are observed only in a small (but not negligible) subset of aCRC, an impressive and growing body of evidence supports HER2 status assessment in patients also affected by CRC. In addition to its already consolidated predictive role to anti-EGFR therapy and the more debated prognostic significance, HER2 could, indeed, be a new targetable alteration in aCRC. The introduction of the HERACLES diagnostic criteria for HER2-positive tumors and the initial efforts to integrate traditional methodologies (IHC and FISH) with arising technologies (NGS and CGS) draw a crucial step forward for the accurate characterization of HER2 status in CRC. Moreover, thanks to the growing availability of specific gene panels, the emerging diagnostic tools (NGS and CGS) and the desirable clinical routine use of liquid biopsy, HER2 assessment should be included in all genetic tests for each CRC patient at the time of diagnosis of advanced disease. Although available data and ongoing clinical trials support HER2 therapeutic role in mostly pretreated aCRC patients, similar positive effects are expected in earlier treatment lines. Ongoing trials are required in order to validate this hypothesis. Additional and ad hoc designed clinical studies investigating different typologies of HER2-directed agents are also required in order to define the optimal treatment sequencing in HER2-positive CRC and the most active and efficacious agents. To date, in absence of randomized data, the inclusion of HER2 status definition in the molecular diagnostic workup of all aCRC patients could allow the speedy referral to clinical HERrelated trials independent of previous treatment history. However, the strong underlying biological rationale, preclinical findings, and clinical results support consideration for the conventional clinical approval of anti-HER2 therapies by regulatory agencies in a context of an orphan molecular subgroup of patients. In our opinion, HER2-targeted therapies compare favorably with emerging therapeutic strategies in aCRC, including BRAF-directed therapy and immune checkpoint inhibitors. In the near future, anti-HER2 agents and their combination with other drugs may integrate the algorithm of aCRC treatment towards an increasingly tailored therapeutic approach to this disease.

Author Contributions: Conceptualization, C.G.; literature search, C.G.; writing-original draft preparation, C.G.; writing-review and editing T.G., G.P., and C.P.; supervision, C.P. All authors have read and agreed to the published version of the manuscript.

Funding: This research received no external funding.

Conflicts of Interest: The authors declare no conflict of interest.

\section{References}

1. SEER Database 2020. Available online: https:// seer.cancer.gov/statfacts/html/colorect.html (accessed on 27 May 2021).

2. Schmoll, H.J.; Van Cutsem, E.; Stein, A.E.; Valentini, V.; Glimelius, B.; Haustermans, K.; Nordlinger, B.; Van de Velde, C.J.; Balmana, J.; Regula, J.; et al. ESMO consensus guidelines for management of patients with metastatic colorectal cancer. Ann. Oncol. 2016, 27, 1386-1422.

3. De Greef, K.; Rolfo, C.; Russo, A.; Chapelle, T.; Bronte, G.; Passiglia, F.; Coelho, A.; Papadimitriou, K.; Peeters, M. Multisciplinary management of patients with liver metastasis from colorectal cancer. World J. Gastroenterol. 2016, 22, 7215-7225. [CrossRef] [PubMed]

4. Overman, M.J.; McDermott, R.; Leach, J.L.; Lonardi, S.; Lenz, H.J.; Morse, M.A.; Desai, J.; Hill, A.; Axelson, M.; Moss, R.A.; et al. Nivolumab in patients with metastatic DNA mismatch repairdeficient or microsatellite instability-high colorectal cancer (CheckMate 142): An open-label, multicentre, phase 2 study. Lancet Oncol. 2017, 18, 1182-1191. [CrossRef]

5. Diaz, L.; Marabelle, A.; Kim, T.W.; Geva, R.; Van Cutsem, E.; André, T.; Ascierto, P.A.; Maio, M.; Delord, J.P.; Gottfried, M.; et al. Efficacy of pembrolizumab in phase 2 KEYNOTE-164 and KEYNOTE-158 studies of microsatellite instability high cancers. Ann. Oncol. 2017, 28, mdx367.020. [CrossRef] 
6. $\quad$ Overman, M.J.; Lonardi, S.; Wong, K.Y.; Lenz, H.J.; Gelsomino, F.; Aglietta, M.; Morse, M.A.; Van Cutsem, E.; McDermott, R.; Hill, A.; et al. Durable clinical benefit with nivolumab plus ipilimumab in dna mismatch repair-deficient/microsatellite instabilityhigh metastatic colorectal cancer. J. Clin. Oncol. 2018, 36, 773-779. [CrossRef]

7. Hochster, H.S.; Bendell, J.C.; Cleary, J.M.; Foster, P.; Zhang, W.; He, X.; Hernandez, G.; Iizuka, K.; Eckhardt, S.G. Efficacy and safety of atezolizumab (atezo) and bevacizumab (bev) in a phase Ib study of microsatellite instability (MSI)-high metastatic colorectal cancer (mCRC). J. Clin. Oncol. 2017, 35, S673. [CrossRef]

8. Lenz, H.J.; Lonardi, S.; Zagonel, V.; Van Cutsem, E.; Limon, M.L.; Wong, K.Y.; Hendlisz, A.; Aglietta, M.; Garcia-Alfonso, P.; Neyns, B.; et al. Nivolumab plus low-dose ipilimumab as first-line therapy in microsatellite instability-high/DNA mismatch repair deficient metastatic colorectal cancer: Clinical update. J. Clin. Oncol. 2020, 38, 11. [CrossRef]

9. André, T.; Shiu, K.K.; Kim, T.W.; Jensen, B.V.; Jensen, L.H.; Punt, C.; Smith, D.; Garcia-Carbonero, R.; Benavides, M.; Gibbs, P.; et al. KEYNOTE-177 Investigators. Pembrolizumab in Microsatellite-Instability-High Advanced Colorectal Cancer. N. Engl. J. Med. 2020, 383, 2207-2218. [CrossRef] [PubMed]

10. Modest, D.P.; Pant, S.; Sartore-Bianchi, A. Treatment sequencing in metastatic colorectal cancer. Eur. J. Cancer 2019, 109, 70-83. [CrossRef] [PubMed]

11. Temraz, S.; Mukherji, D.; Shamseddine, A. Sequencing of treatment in metastatic colorectal cancer: Where to fit the target. World J. Gastroenterol. 2014, 20, 1993-2004. [CrossRef]

12. Seymour, M.T.; Thompson, L.C.; Wasan, H.S.; Middleton, G.; Brewster, A.E.; Shepherd, S.F.; O’Mahony, M.S.; Maughan, T.S.; Parmar, M.; Langley, R.E.; et al. Chemotherapy options in elderly and frail patients with metastatic colorectal cancer (MRC FOCUS2): An open-label, randomised factorial trial. Lancet 2011, 377, 1749-1759. [CrossRef]

13. Cunningham, D.; Lang, I.; Marcuello, E.; Lorusso, V.; Ocvirk, J.; Shin, D.B.; Jonker, D.; Osborne, S.; Andre, N.; Waterkamp, D.; et al. Bevacizumab plus capecitabine versus capecitabine alone in elderly patients with previously untreated metastatic colorectal cancer (AVEX): An open-label, randomised phase 3 trial. Lancet Oncol. 2013, 14, 1077-1085. [CrossRef]

14. Price, T.J.; Zannino, D.; Wilson, K.; Simes, R.J.; Cassidy, J.; Van Hazel, G.A.; Robinson, B.A.; Broad, A.; Ganju, V.; Ackland, S.P.; et al. Bevacizumab is equally effective and no more toxic in elderly patients with advanced colorectal cancer: A subgroup analysis from the AGITG MAX trial. Ann. Oncol. 2012, 23, 1531-1536. [CrossRef]

15. Holch, J.W.; Ricard, I.; Stintzing, S.; Modest, D.P.; Heinemann, V. The relevance of primary tumour location in patients with metastatic colorectal cancer: A meta-analysis of first-line clinical trials. Eur. J. Cancer 2017, 70, 87-98. [CrossRef] [PubMed]

16. Arnold, D.; Lueza, B.; Douillard, J.Y.; Peeters, M.; Lenz, H.J.; Venook, A.; Heinemann, V.; Van Cutsem, E.; Pignon, J.P.; Tabernero, J.; et al. Prognostic and predictive value of primary tumour side in patients with RAS wild-type metastatic colorectal cancer treated with chemo and EGFR directed antibodies. Ann. Oncol. 2017, 28, 1713-1729. [CrossRef] [PubMed]

17. Brule, S.Y.; Jonker, D.J.; Karapetis, C.S.; O'Callaghan, C.J.; Moore, M.J.; Wong, R.; Tebbutt, N.C.; Underhill, C.; Yip, D.; Zalcberg, J.R.; et al. Location of colon cancer (right-sided versus left-sided) as a prognostic factor and a predictor of benefit from cetuximab in NCIC CO.17. Eur. J. Cancer 2015, 51, 1405-1414. [CrossRef]

18. Petrelli, F.; Tomasello, G.; Borgonovo, K.; Ghidini, M.; Turati, L.; Dallera, P.; Passalacqua, R.; Sgroi, G.; Barni, S. Prognostic survival associated with left-sided vs right-sided colon cancer. A systematic review and meta-analysis. JAMA Oncol. 2016, 3, 211-219. [CrossRef]

19. Douillard, J.-Y.; Oliner, K.S.; Siena, S.; Tabernero, J.; Burkes, R.; Barugel, M.; Humblet, Y.; Bodoky, G.; Cunningham, D.; Jassem, J.; et al. Panitumumab-FOLFOX4 treatment and RAS mutations in colorectal cancer. N. Engl. J. Med. 2013, 369, 1023-1034. [CrossRef]

20. Andreyev, H.J.; Norman, A.R.; Clarke, P.A.; Cunningham, D.; Oates, J.R. Kirsten ras mutations in patients with colorectal cancer: The multicenter "RASCAL" study. J. Natl. Cancer Inst. 1998, 90, 675-684. [CrossRef]

21. Loupakis, F.; Cremolini, C.; Salvatore, L.; Masi, G.; Sensi, E.; Schirripa, M.; Michelucci, A.; Pfanner, E.; Brunetti, I.; Lupi, C.; et al. FOLFOXIRI plus bevacizumab as first-line treatment in BRAF mutant metastatic colorectal cancer. Eur. J. Cancer 2014, 50, 57-63. [CrossRef]

22. Bokemeyer, C.; Bondarenko, I.; Hartmann, J.T.; de Braud, F.G.M.; Schuch, G.; Zubel, A.; Celik, I.; Schlichting, M.; Koralewski, P. Efficacy according to biomarker status of cetuximab plus FOLFOX-4 as first-line treatment for metastatic colorectal cancer: The OPUS study. Ann. Oncol. 2011, 22, 1535-1546. [CrossRef]

23. Pentheroudakis, G.; Kotoula, V.; De Roock, W.; Kouvatseas, G.; Papakostas, P.; Makatsoris, T.; Papamichael, D.; Xanthakis, I.; Sgouros, J.; Televantou, D.; et al. Biomarkers of benefit from cetuximab-based therapy in metastatic colorectal cancer: Interaction of EGFR ligand expression with RAS/RAF, PIK3CA genotypes. BMC Cancer 2013, 13, 49. [CrossRef]

24. Chen, J.; Ye, Y.; Sun, H.; Shi, G. Association between KRAS codon 13 mutations and clinical response to anti-EGFR treatment in patients with metastatic colorectal cancer: Results from a meta-analysis. Cancer Chemother. Pharm. 2013, 71, 265-272. [CrossRef]

25. Peeters, M.; Douillard, J.-Y.; Van Cutsem, E.; Siena, S.; Zhang, K.; Williams, R.; Wiezorek, J. Mutant KRAS codon 12 and 13 alleles in patients with metastatic colorectal cancer: Assessment as prognostic and predictive biomarkers of response to panitumumab. $J$. Clin. Oncol. 2013, 31, 759-765. [CrossRef]

26. Roth, A.D.; Tejpar, S.; Delorenzi, M.; Yan, P.; Fiocca, R.; Klingbiel, D.; Dietrich, D.; Biesmans, B.; Bodoky, G.; Barone, C.; et al. Prognostic role of KRAS and BRAF in stage II and III resected colon cancer: Results of the translational study onthe PETACC-3, EORTC 40993, SAKK 60-00 trial. J. Clin. Oncol. 2010, 28, 466-474. [CrossRef] [PubMed] 
27. Schirripa, M.; Cremolini, C.; Loupakis, F.; Morvillo, M.; Bergamo, F.; Zoratto, F.; Salvatore, L.; Antoniotti, C.; Marmorino, F.; Sensi, E.; et al. Role of NRAS mutations as prognostic and predictive markers in metastatic colorectal cancer. Int. J. Cancer 2015, 136, 83-90. [CrossRef]

28. Matallanas, D.; Birtwistle, M.; Romano, D.; Zebisch, A.; Rauch, J.; von Kriegsheim, A.; Kolch, W. Raf family kinases: Old dogs have learned new tricks. Genes Cancer 2011, 2, 232-260. [CrossRef] [PubMed]

29. Wan, P.T.; Garnett, M.J.; Roe, S.M.; Lee, S.; Niculescu-Duvaz, D.; Good, V.M.; Cancer Genome Project; Jones, C.M.; Marshall, C.J.; Springer, C.J.; et al. Mechanism of activation of the RAF- ERK signaling pathway by oncogenic mutations of B-RAF. Cell 2004, 116, 855-867. [CrossRef]

30. Richman, S.D.; Seymour, M.T.; Chambers, P.; Elliott, F.; Daly, C.L.; Meade, A.M.; Taylor, G.; Barrett, J.H.; Quirke, P. KRAS and BRAF mutations in advanced colorectal cancer are associated with poor prognosis but do not preclude benefit from oxaliplatin or irinotecan: Results from theMRC FOCUS trial. J. Clin. Oncol. 2009, 27, 5931-5937. [CrossRef]

31. Tie, J.; Gibbs, P.; Lipton, L.; Christie, M.; Jorissen, R.N.; Burgess, A.W.; Croxford, M.; Jones, I.; Langland, R.; Kosmider, S.; et al. Optimizing targeted therapeutic develop- ment: Analysis of a colorectal cancer patient population with the BRAF(V600E) mutation. Int. J. Cancer 2011, 128, 2075-2084. [CrossRef] [PubMed]

32. Hecht, J.R.; Douillard, J.Y.; Schwartzberg, L.; Grothey, A.; Kopetz, S.; Rong, A.; Oliner, K.S.; Sidhu, R. Extended RAS analysis for anti-epidermal growth factor therapy in patients with metastatic colorectal cancer. Cancer Treat. Rev. 2015, 41, 653-659. [CrossRef]

33. Davies, H.; Bignell, G.R.; Cox, C.; Stephens, P.; Edkins, S.; Clegg, S.; Teague, J.; Woffendin, H.; Garnett, M.J.; Bottomley, W.; et al. Mutations of the BRAF gene in human cancer. Nature 2002, 417, 949-954. [CrossRef] [PubMed]

34. Yokota, T.; Ura, T.; Shibata, N.; Takahari, D.; Shitara, K.; Nomura, M.; Kondo, C.; Mizota, A.; Utsunomiya, S.; Muro, K.; et al. BRAF mutation is a powerful prognostic factor in advanced and recurrent colorectal cancer. Br. J. Cancer 2011, 104, 856-862. [CrossRef] [PubMed]

35. Samowitz, W.S.; Sweeney, C.; Herrick, J.; Albertsen, H.; Levin, T.R.; Murtaugh, M.A.; Wolff, R.K.; Slattery, M.L. Poor survival associated with the BRAF V600E mutation in microsatellite-stable colon cancers. Cancer Res. 2005, 65, 6063-6910. [CrossRef] [PubMed]

36. Yuan, Z.X.; Wang, X.Y.; Qin, Q.Y.; Chen, D.F.; Zhong, Q.H.; Wang, L.; Wang, J.P. The prognostic role of BRAF mutation in metastatic colorectal cancer receiving anti-EGFR monoclonal antibodies: A meta-analysis. PLoS ONE 2013, 8, e65995. [CrossRef] [PubMed]

37. Kopetz, S.; Chang, G.J.; Overman, M.J.; Eng, C.; Sargent, D.J.; Larson, D.W.; Grothey, A.; Vauthey, J.N.; Nagorney, D.M.; McWilliams, R.R. Improved survival in metastatic colorectal cancer is associated with adoption of hepatic resection and improved chemotherapy. J. Clin. Oncol. 2009, 27, 3677. [CrossRef] [PubMed]

38. Cremolini, C.; Schirripa, M.; Antoniotti, C.; Moretto, R.; Salvatore, L.; Masi, G.; Falcone, A.; Loupakis, F. First-line chemotherapy for mCRC-a review and evidence-based algorithm. Nat. Rev. Clin. Oncol. 2015, 12, 607-619. [CrossRef]

39. Fearon, E.R. Molecular genetics of colorectal cancer. Annu. Rev. Pathol. 2011, 6, 479-507. [CrossRef]

40. Fearon, E.R.; Vogelstein, B. A genetic model for colorectal tumorigenesis. Cell 1990, 61, 759-767. [CrossRef]

41. Vogelstein, B.; Fearon, E.R.; Hamilton, S.R.; Kern, S.E.; Preisinger, A.C.; Leppert, M.; Smits, A.M.; Bos, J.L. Genetic alterations during colorectal-tumor development. N. Engl. J. Med. 1988, 319, 525-532. [CrossRef] [PubMed]

42. Vogelstein, B.; Papadopoulos, N.; Velculescu, V.E.; Zhou, S.; Diaz, L.A.; Kinzler, K.W. Cancer genome land- scapes. Science 2013, 339, 1546-1558. [CrossRef]

43. Ahn, D.H.; Ciombor, K.K.; Mikhail, S.; Bekaii-Saab, T. Genomic diversity of colorectal cancer: Changing landscape and emerging targets. World J. Gastroenterol. 2016, 22, 5668-5677. [CrossRef]

44. Guinney, J.; Dienstmann, R.; Wang, X.; De Reynies, A.; Schlicker, A.; Soneson, C.; Marisa, L.; Roepman, P.; Nyamundanda, G.; Angelino, P.; et al. The consensus molecular subtypes of colorectal cancer. Nat. Med. 2015, 21, 1350-1356. [CrossRef] [PubMed]

45. Gong, J.; Cho, M.; Sy, M.; Salgia, R.; Fakih, M. Molecular profiling of metastatic colorectal tumors using next-generation sequencing: A single-institution experience. Oncotarget 2017, 8, 42198-42213. [CrossRef] [PubMed]

46. Cremolini, C.; Morano, F.; Moretto, R.; Berenato, R.; Tamborini, E.; Perrone, F.; Rossini, D.; Gloghini, A.; Busico, A.; Zucchelli, G.; et al. Negative hyper-selection of metastatic colorectal cancer patients for anti-EGFR monoclonal antibodies: The PRESSING case-control study. Ann. Oncol. 2017, 28, 3009-3014. [CrossRef]

47. Sartore-Bianchi, A.; Marsoni, S.; Siena, S. Human Epidermal Growth Factor Receptor 2 as a Molecular Biomarker for Metastatic Colorectal Cancer. JAMA Oncol. 2018, 4, 19-20. [CrossRef] [PubMed]

48. Popescu, N.C.; King, C.R.; Kraus, M.H. Localization of the human erbB-2 gene on normal and rearranged chromosomes 17 to bands q12-21.32. Genomics 1989, 4, 362-366. [CrossRef]

49. Martin, V.; Cappuzzo, F.; Mazzucchelli, L.; Frattini, M. HER2 in solidtumors: More than 10 years under the microscope; where are we now? Future Oncol. 2014, 10, 1469-1486. [CrossRef]

50. Graus-Porta, D.; Beerli, R.R.; Daly, J.M.; Hynes, N.E. ErbB-2, the preferred heterodimerization partner of all ErbB receptor, is a mediator of lateral signaling. EMBO J. 1997, 16, 1647-1655. [CrossRef]

51. Moasser, M.M. The oncogene HER2: Its signaling and transforming functions and its role in human cancer pathogenesis. Oncogene 2007, 26, 6469-6487. [CrossRef] [PubMed]

52. Yarden, Y.; Sliwkowski, M.X. Untangling the ErbB signalling network. Nat. Rev. Mol. Cell Biol. 2001, 2, 127-137. [CrossRef] 
53. Benlimame, N.; He, Q.; Jie, X.Y.; Xiao, D.; Xu, Y.J.; Loignon, M.; Schlaepfer, D.D.; Alaoui-Jamali, M.A. FAK signaling is critical for ErbB-2/ErbB-3 receptor cooperation for oncogenic transformation and invasion. J. Cell Biol. 2005, 171, 505-516. [CrossRef]

54. Neve, R.M.; Lane, H.A.; Hynes, N.E. The role of overexpressed HER2 in transformation. Ann. Oncol. 2001, 12 (Suppl. S1), S9-S13. [CrossRef]

55. Tzahar, E.; Waterman, H.; Chen, X.; Levkowitz, G.; Karunagaran, D.; Lavi, S.; Ratzkin, B.J.; Yarden, Y. A hierarchical network of interreceptor interactions determines signal transduction by Neu differentiation factor/neuregulin and epidermal growth factor. Mol. Cell Biol. 1996, 16, 5276-5287. [CrossRef]

56. Holbro, T.; Beerli, R.R.; Maurer, F.; Koziczak, M.; Barbas, C.F.; Hynes, N.E. The ErbB2/ErbB3 heterodimer functions as an oncogenic unit: ErbB2 requires ErbB3 to drive breast tumor cell proliferation. Proc. Natl. Acad. Sci. USA 2003, 100, 8933-8938. [CrossRef]

57. Alimandi, M.; Romano, A.; Curia, M.C.; Muraro, R.; Fedi, P.; Aaronson, S.A.; Di Fiore, P.P.; Kraus, M.H. Cooperative signaling of ErbB3 and ErbB2 in neoplastic transformation and human mammary carcinomas. Oncogene 1995, 10, 1813-1821. [PubMed]

58. Gutierrez, C.; Schiff, R. HER2: Biology, detection, and clinical implications. Arch. Pathol. Lab. Med. 2011, 135, 55-62. [CrossRef]

59. Arteaga, C.L.; Engelman, J.A. ERBB receptors: From oncogene discovery to basic science to mechanism-based cancer therapeutics. Cancer Cell 2014, 25, 282-303. [CrossRef] [PubMed]

60. Meric-Bernstam, F.; Hurwitz, H.; Raghav, K.P.S.; McWilliams, R.R.; Fakih, M.; VanderWalde, A.; Swanton, C.; Kurzrock, R.; Burris, H.; Sweeney, C.; et al. Pertuzumab plus trastuzumab for HER2-amplified metastatic colorectal cancer (MyPathway): An updated report from a multicentre, open-label, phase 2a, multiple basket study. Lancet 2019, 20, 518-530. [CrossRef]

61. Gschwind, A.; Fischer, O.M.; Ullrich, A. The discovery of receptor tyrosine kinases: Targets for cancer therapy. Nat. Rev. Cancer 2004, 4, 361-370. [CrossRef]

62. Slamon, D.J.; Clark, G.M.; Wong, S.G.; Levin, W.J.; Ullrich, A.; McGuire, W.L. Human breast cancer: Correlation of relapse and survival with amplification of the HER-2/neu oncogene. Science 1987, 235, 177-182. [CrossRef]

63. Press, M.F.; Bernstein, L.; A Thomas, P.; Meisner, L.F.; Zhou, J.Y.; Ma, Y.; Hung, G.; A Robinson, R.; Harris, C.; El-Naggar, A.; et al. HER-2/neu gene amplification characterized by fluorescence in situ hybridization: Poor prognosis in node-negative breast carcinomas. J. Clin. Oncol. 1997, 15, 2894-2904. [CrossRef]

64. Hynes, N.E.; Stern, D.F. The biology of erbB-2/neu/HER-2 and its role in cancer. Biochim Biophys Acta 1994, 1198, 165-184. [PubMed]

65. Iqbal, N.; Iqbal, N. Human Epidermal Growth Factor Receptor 2 (HER2) in Cancers: Overexpression and Therapeutic Implications. Mol. Biol. Int. 2014, 2014, 852748. [CrossRef]

66. Ménard, S.; Pupa, S.M.; Campiglio, M.; Tagliabue, E. Biologic and therapeutic role of HER2 in cancer. Oncogene 2003, 22, 6570-6578. [CrossRef] [PubMed]

67. Burstein, H.J. The distinctive nature of HER2-positive breast cancers. N. Engl. J. Med. 2005, 353, 1652-1654. [CrossRef]

68. Nuciforo, P.; Thyparambil, S.; Aura, C.; Garrido-Castro, A.; Vilaro, M.; Peg, V.; Jimenez, J.; Vicario, R.; Cecchi, F.; Hoos, W.; et al. High HER2 protein levels correlate with increased survival in breast cancer patients treated with anti-HER2 therapy. Mol. Oncol. 2016, 10, 138-147. [CrossRef]

69. Fornaro, L.; Lucchesi, M.; Caparello, C.; Vasile, E.; Caponi, S.; Ginocchi, L.; Masi, G.; Falcone, A. Anti-HER agents in gastric cancer: From bench to bedside. Nat. Rev. Gastroenterol. Hepatol. 2011, 8, 369-383. [CrossRef] [PubMed]

70. Bang, Y.-J.; Van Cutsem, E.; Feyereislova, A.; Chung, H.; Shen, L.; Sawaki, A.; Lordick, F.; Ohtsu, A.; Omuro, Y.; Satoh, T.; et al. Trastuzumab in combination with chemotherapy versus chemotherapy alone for treatment of HER2-positive advanced gastric or gastro-oesophageal junction cancer (ToGA). Lancet 2010, 376, 687-697. [CrossRef]

71. Wolff, A.C.; Hammond, M.E.; Allison, K.H.; Harvey, B.E.; McShane, L.M.; Dowsett, M. Recommendations for HER 2 testing in breast cancer: American Society of Clinical Oncology/College of American Pathologists clinical practice guideline update. J. Clin. Oncol. 2013, 31, 3997-4013. [CrossRef] [PubMed]

72. Cameron, D.; Piccart-Gebhart, M.J.; Gelber, R.D.; Procter, M.; Goldhirsch, A.; de Azambuja, E.; Castro, G.; Untch, M.; Smith, I.; Gianni, L.; et al. 11 years' follow-up of trastuzumab after adjuvant chemotherapy in HER2-positive early breast cancer: Final analysis of the HERceptin Adjuvant (HERA) trial. Lancet 2017, 389, 1195-1205. [CrossRef]

73. Langer, C.J.; Stephenson, P.; Thor, A.; Vangel, M.; Johnson, D.H. Trastuzumab in the treatment of advanced non-small-cell lung cancer: Is there a role? Focus on Eastern Cooperative Oncology Group Study 2598. J. Clin. Oncol. 2004, 22, 1180-1187. [CrossRef] [PubMed]

74. Hussain, M.H.; MacVicar, G.R.; Petrylak, D.P.; Dunn, R.L.; Vaishampayan, U.; Lara, P.N., Jr.; Chatta, G.S.; Nanus, D.M.; Glode, L.M.; Trump, D.L.; et al. Trastuzumab, paclitaxel, carboplatin, and gemcitabine in advanced HER-2/neu-positive urothelial carcinoma: Results of a multicenter phase II National Cancer Institute trial. J. Clin. Oncol. 2007, 25, 2218-2224. [CrossRef] [PubMed]

75. Gargano, S.M.; Senarathne, W.; Feldman, R.; Florento, E.; Stafford, P.; Swensen, J.; Vranic, S.; Gatalica, Z. Novel therapeutic targets in salivary duct carcinoma uncovered by comprehensive molecular profiling. Cancer Med. 2019, 8, 7322-7329. [CrossRef] [PubMed]

76. Yamamoto, H.; Higasa, K.; Sakaguchi, M.; Shien, K.; Soh, J.; Ichimura, K.; Furukawa, M.; Hashida, S.; Tsukuda, K.; Takigawa, N.; et al. Novel germline mutation in the transmembrane domain of HER2 in familial lung adenocarcinomas. J. Natl. Cancer Inst. 2014, 106, djt338. [CrossRef] [PubMed] 
77. Shigematsu, H.; Takahashi, T.; Nomura, M.; Majmudar, K.; Suzuki, M.; Lee, H.; Wistuba, I.I.; Fong, K.M.; Toyooka, S.; Shimizu, N.; et al. Somatic mutations of the HER2 kinase domain in lung adenocarcinomas. Cancer Res. 2005, 65, $1642-1646$. [CrossRef] [PubMed]

78. Li, C.; Sun, Y.; Fang, R.; Han, X.; Luo, X.; Wang, R.; Pan, Y.; Hu, H.; Zhang, Y.; Pao, W.; et al. Lung adenocarcinomas with HER2-activating mutations are associated with distinct clinical features and HER2/EGFR copy number gains. J. Thorac Oncol. 2012, 7, 85-89. [CrossRef]

79. Petrelli, F.; Tomasello, G.; Barni, S.; Lonati, V.; Passalacqua, R.; Ghidini, M. Clinical and pathological characterization of HER2 mutations in human breast cancer: A systematic review of the literature. Breast Cancer Res. Treat. 2017, 166, 339-349. [CrossRef]

80. Yu, D.-H.; Tang, L.; Dong, H.; Dong, Z.; Zhang, L.; Fu, J.; Su, X.; Zhang, T.; Fu, H.; Han, L.; et al. Oncogenic HER2 fusions in gastric cancer. J. Transl. Med. 2015, 13, 116. [CrossRef]

81. Wen, W.; Chen, W.; Xiao, N.; Bender, R.; Ghazalpour, A.; Tan, Z.; Swensen, J.; Millis, S.Z.; Basu, G.; Gatalica, Z.; et al. Mutations in the Kinase Domain of the HER2/ERBB2 Gene Identified in a Wide Variety of Human Cancers. J. Mol. Diagn. 2015, 17, 487-495. [CrossRef]

82. Ross, J.S.; Wang, K.; Gay, L.M.; Al-Rohil, R.N.; Nazeer, T.; Sheehan, C.E.; Jennings, T.A.; Otto, G.A.; Donahue, A.; He, J.; et al. A high frequency of activating extracellular domain ERBB2 (HER2) mutation in micropapillary urothelial carcinoma. Clin. Cancer Res. 2014, 20, 68-75. [CrossRef]

83. Zabransky, D.J.; Yankaskas, C.; Cochran, R.L.; Wong, H.Y.; Croessmann, S.; Chu, D.; Kavuri, S.M.; Brewer, M.R.; Rosen, D.M.; Dalton, W.; et al. HER2 missense mutations have distinct effects on oncogenic signaling and migration. Proc. Natl. Acad. Sci. USA 2015, 112, E6205-E6214. [CrossRef] [PubMed]

84. Wang, G.; He, Y.; Sun, Y.; Wang, W.; Qian, X.; Yu, X.; Pan, Y. Prevalence, prognosis and predictive status of HER2 amplification in anti-EGFR-resistant metastatic colorectal cancer. Clin. Transl. Oncol. 2020, 22, 813-822. [CrossRef]

85. Na Seo, A.; Kwak, Y.; Kim, D.-W.; Kang, S.-B.; Choe, G.; Kim, W.H.; Lee, H.S. HER2 status in colorectal cancer: Its clinical significance and the relationship between HER2 gene amplification and expression. PLoS ONE 2014, 9, e98528.

86. Heppner, B.I.; Behrens, H.M.; Balschun, K.; Haag, J.; Krüger, S.; Becker, T.; Röcken, C. HER2/neu testing in primary colorectal carcinoma. Br. J. Cancer 2014, 111, 1977-1984. [CrossRef]

87. Richman, S.D.; Southward, K.; Chambers, P.; Cross, D.; Barrett, J.; Hemmings, G.; Taylor, M.; Wood, H.; Hutchins, G.; Foster, J.M.; et al. HER2 overexpression and amplification as a potential therapeutic target in colorectal cancer: Analysis of 3256 patients enrolled in the QUASAR, FOCUS and PICCOLO colorectal cancer trials. J. Pathol. 2016, 238, 562-570. [CrossRef] [PubMed]

88. Shabbir, A.; Mirza, T.; Khalid, A.B.; Qureshi, M.A.; Asim, S.A. Frequency of Her2/neu expression in colorectal adenocarcinoma: A study from developing South Asian Country. BMC Cancer 2016, 16, 855. [CrossRef]

89. Blok, E.J.; Kuppen, P.; Van Leeuwen, J.E.; Sier, C.F. Cytoplasmic Overexpression of HER2: A Key Factor in Colorectal Cancer. Clin. Med. Insights Oncol. 2013, 7, 41-51. [CrossRef]

90. Marx, A.H.; Burandt, E.C.; Choschzick, M.; Simon, R.; Yekebas, E.; Kaifi, J.T.; Mirlacher, M.; Atanackovic, D.; Bokemeyer, C.; Fiedler, W.; et al. Heterogenous high-level HER-2 amplification in a small subset of colorectal cancers. Hum. Pathol. 2010, 41, 1577-1585. [CrossRef]

91. Buhmeida, A.; Assidi, M.; Al-Maghrabi, J.; Dallol, A.; Sibiany, A.; Al-Ahwal, M.; Chaudhary, A.; Abuzenadah, A.; Al-Qahtani, M. Membranous or Cytoplasmic HER2 Expression in Colorectal Carcinoma: Evaluation of Prognostic Value Using Both IHC \& BDISH. Cancer Investig. 2018, 36, 129-140.

92. Valtorta, E.; Martino, C.; Sartore-Bianchi, A.; Penaullt-Llorca, F.; Viale, G.; Risio, M.; Rugge, M.; Grigioni, W.; Bencardino, K.; Lonardi, S.; et al. Assessment of a HER2 scoring system for colorectal cancer: Results from a validation study. Mod. Pathol. 2015, 28, 1481-1491. [CrossRef] [PubMed]

93. TCGA. Comprehensive molecular characterization of human colon and rectal cancer. Nature 2012, 487, 330-337. [CrossRef] [PubMed]

94. Lee, W.; Park, Y.H.; Lee, J.N.; Baek, J.; Lee, T.; Ha, S.Y. Comparison of HER2 expression between primary colorectal cancer and their corresponding metastases. Cancer Med. 2014, 3, 674-680. [CrossRef] [PubMed]

95. Shan, L.; Lv, Y.; Bai, B.; Huang, X.; Zhu, H. Variability in HER2 expression between primary colorectal cancer and corresponding metastases. J. Cancer Res. Clin. Oncol. 2018, 144, 2275-2281. [CrossRef]

96. Salem, M.E.; Weinberg, B.A.; Xiu, J.; El-Deiry, W.S.; Hwang, J.J.; Gatalica, Z.; Philip, P.A.; Shields, A.F.; Lenz, H.-J.; Marshall, J.L. Comparative molecular analyses of left-sided colon, right-sided colon, and rectal cancers. Oncotarget 2017, 8, 86356-86368. [CrossRef]

97. Loree, J.; Pereira, A.; Lam, M.; Willauer, A.; Raghav, K.; Dasari, A.; Morris, V.K.; Advani, S.M.; Menter, D.G.; Eng, C.; et al. Classifying Colorectal Cancer by Tumor Location Rather than Sidedness Highlights a Continuum in Mutation Profiles and Consensus Molecular Subtypes. Clin. Cancer Res. 2018, 24, 1062-1072. [CrossRef]

98. Stintzing, S.; Tejpar, S.; Gibbs, P.; Thiebach, L.; Lenz, H.-J. Understanding the role of primary tumour localisation in colorectal cancer treatment and outcomes. Eur. J. Cancer 2017, 84, 69-80. [CrossRef] [PubMed]

99. Qiu, M.; He, C.; Yang, X.; Yang, L.; Lin, J.; Zhou, D.; Long, Y.; Guan, W.; Jin, Y.; Li, Y.; et al. Relationship of HER2 Alteration and Microsatellite Instability Status in Colorectal Adenocarcinoma. Oncologist 2021. [CrossRef] 
100. Kavuri, S.M.; Jain, N.; Galimi, F.; Cottino, F.; Leto, S.M.; Migliardi, G.; Searleman, A.; Shen, W.; Monsey, J.D.; Trusolino, L.; et al. HER2 activating mutations are targets for colorectal cancer treatment. Cancer Discov. 2015, 5, 832-841. [CrossRef]

101. Sartore-Bianchi, A.; Trusolino, L.; Martino, C.; Bencardino, K.; Lonardi, S.; Bergamo, F.; Zagonel, V.; Leone, F.; Depetris, I.; Martinelli, E.; et al. Dual-targeted therapy with trastuzumab and lapatinib in treatment-refractory, KRAS codon 12/13 wild-type, HER2-positive metastatic colorectal cancer (HERACLES). Lancet Oncol. 2016, 17, 738-746. [CrossRef]

102. Siena, S.; Sartore-Bianchi, A.; Marsoni, S.; Hurwitz, H.; McCall, S.; Penault-Llorca, F.; Srock, S.; Bardelli, A.; Trusolino, L. Targeting the human epidermal growth factor receptor 2 (HER2) oncogene in colorectal cancer. Ann. Oncol. 2018, 29, 1108-1119. [CrossRef] [PubMed]

103. Rüschoff, J.; Hanna, W.; Bilous, M.; Hofmann, M.; Osamura, R.Y.; Penault-Llorca, F.; Van De Vijver, M.; Viale, G. HER2 testing in gastric cancer: A practical approach. Mod. Pathol. 2012, 25, 637-650. [CrossRef] [PubMed]

104. Bartley, A.N.; Washington, M.K.; Ventura, C.B.; Ismaila, N.; Colasacco, C.; Benson, I.I.I.A.B.; Carrato, A.; Gulley, M.L.; Jain, D.; Kakar, S.; et al. HER2 Testing and Clinical Decision Making in Gastroesophageal Adenocarcinoma: Guideline from the College of American Pathologists. Arch. Pathol. Lab. Med. 2016, 140, 1345-1363. [CrossRef] [PubMed]

105. Liu, F.; Ren, C.; Jin, Y.; Xi, S.; He, C.; Wang, F.; Wang, Z.; Xu, R.-H.; Wang, F. Assessment of two different HER2 scoring systems and clinical relevance for colorectal cancer. Virchows. Arch. 2020, 476, 391-398. [CrossRef]

106. Takegawa, N.; Yonesaka, K.; Sakai, K.; Ueda, H.; Watanabe, S.; Nonagase, Y.; Okuno, T.; Takeda, M.; Maenishi, O.; Tsurutani, J. HER2 genomic amplification in circulating tumor DNA from patients with cetuximab-resistant colorectal cancer. Oncotarget 2016, 7, 3453-3460. [CrossRef] [PubMed]

107. Edenfield, W.J.; Chung, K.Y.; Gatalica, Z.; Basu, G.D. Molecular profiling of HER2-positive colorectal cancer for identification of multiple potential drug targets. J. Clin. Oncol. 2014, 32 (Suppl. S15), e14508. [CrossRef]

108. Shimada, Y.; Yagi, R.; Kameyama, H.; Nagahashi, M.; Ichikawa, H.; Tajima, Y.; Okamura, T.; Nakano, M.; Nakano, M.; Sato, Y.; et al Utility of comprehensive genomic sequencing for detecting HER2-positive colorectal cancer. Hum. Pathol. 2017, 66, 1-9. [CrossRef]

109. Kerkhof, J.; Schenkel, L.C.; Reilly, J.; McRobbie, S.; Aref-Eshghi, E.; Stuart, A.; Rupar, C.A.; Adams, P.; Hegele, R.A.; Lin, H.; et al. Clinical validation of copy number variant detection from targeted next-generation sequencing panels. J. Mol. Diagn. 2017, 19, 905-920. [CrossRef]

110. Fujii, S.; Magliocco, A.M.; Kim, J.; Okamoto, W.; Kim, J.E.; Sawada, K.; Nakamura, Y.; Kopetz, S.; Park, W.Y.; Tsuchihara, K.; et al. International harmonization of provisional diagnostic criteria for ErbB2-amplified metastatic colorectal cancer allowing for screening by next-generation sequencing panel. JCO Precis. Oncol. 2020, 4, 6-19. [CrossRef]

111. Normanno, N.; Cervantes, A.; Ciardiello, F.; De Luca, A.; Pinto, C. The liquid biopsy in the management of colorectal cancer patients: Current applications and future scenarios. Cancer Treat. Rev. 2018, 70, 1-8. [CrossRef]

112. Castro-Giner, F.; Gkountela, S.; Donato, C.; Alborelli, I.; Quagliata, L.; Ng, C.K.Y.; Piscuoglio, S.; Aceto, N. Cancer Diagnosis Using a Liquid Biopsy: Challenges and Expectations. Diagnostics 2018, 8, 31. [CrossRef] [PubMed]

113. Siravegna, G.; Mussolin, B.; Buscarino, M.; Corti, G.; Cassingena, A.; Crisafulli, G.; Ponzetti, A.; Cremolini, C.; Amatu, A.; Lauricella, C.; et al. Clonal evolution and resistance to EGFR blockade in the blood of colorectal cancer patients. Nat. Med. 2015, 21, 795-801. [CrossRef]

114. Bertotti, A.; Migliardi, G.; Galimi, F.; Sassi, F.; Torti, D.; Isella, C.; Corà, D.; Di Nicolantonio, F.; Buscarino, M.; Petti, C.; et al. A molecularly annotated platform of patient-derived xenografts ("xenopatients") identifies HER2 as an effective therapeutic target in cetuximab-resistant colorectal cancer. Cancer Discov. 2011, 1, 508-523. [CrossRef]

115. Yonesaka, K.; Zejnullahu, K.; Okamoto, I.; Satoh, T.; Cappuzzo, F.; Souglakos, J.; Ercan, D.; Rogers, A.; Roncalli, M.; Takeda, M.; et al. Activation of ERBB2 signaling causes resistance to the EGFR-directed therapeutic antibody cetuximab. Sci. Transl. Med. 2011, 3, 99ra86. [CrossRef] [PubMed]

116. Mohan, S.; Heitzer, E.; Ulz, P.; Lafer, I.; Lax, S.; Auer, M.; Pichler, M.; Gerger, A.; Eisner, F.; Hoefler, G.; et al. Changes in colorectal carcinoma genomes under anti-EGFR therapy identified by whole-genome plasma DNA sequencing. PLoS Genet. 2014, 10, e1004271. [CrossRef] [PubMed]

117. Martin, V.; Landi, L.; Molinari, F.; Fountzilas, G.; Geva, R.; Riva, A.; Saletti, P.; De Dosso, S.; Spitale, A.; Tejpar, S.; et al. HER2 gene copy number status may influence clinical efficacy to anti-EGFR monoclonal antibodies in metastatic colorectal cancer patients. Br. J. Cancer 2013, 108, 668-675. [CrossRef] [PubMed]

118. Sawada, K.; Nakamura, Y.; Yamanaka, T.; Kuboki, Y.; Yamaguchi, D.; Yuki, S.; Yoshino, T.; Komatsu, Y.; Sakamoto, N.; Okamoto, W.; et al. Prognostic and predictive value of HER2 amplification in patients with metastatic colorectal cancer. Clin. Colorectal Cancer 2018, 17, 198-205. [CrossRef]

119. Raghav, K.P.S.; Overman, M.J.; Yu, R.; Meric-Bernstam, F.; Menter, D.; Kee, B.K.; Muranyi, A.; Singh, S.; Routbort, M.; Chen, K.; et al. HER2 amplification as a negative predictive biomarker for anti-epidermal growth factor receptor antibody therapy in metastatic colorectal cancer. J. Clin. Oncol. 2016, 34, 3517. [CrossRef]

120. Sartore-Bianchi, A.; Amatu, A.; Porcu, L.; Ghezzi, S.; Lonardi, S.; Leone, F.; Bergamo, F.; Fenocchio, E.; Martinelli, E.; Borelli, B.; et al. HER2 Positivity Predicts Unresponsiveness to EGFR-Targeted Treatment in Metastatic Colorectal Cancer. Oncologist 2019, 24, 1395-1402. [CrossRef]

121. Morano, F.; Corallo, S.; Lonardi, S.; Raimondi, A.; Cremolini, C.; Rimassa, L.; Murialdo, R.; Zaniboni, A.; Sartore-Bianchi, A.; Tomasello, G.; et al. Negative Hyperselection of Patients with RAS and BRAF Wild-Type Metastatic Colorectal Cancer Who Received Panitumumab-Based Maintenance Therapy. J. Clin. Oncol. 2019, 37, 3099-3110. [CrossRef] 
122. Pietrantonio, F.; Vernieri, C.; Siravegna, G.; Mennitto, A.; Berenato, R.; Perrone, F.; Gloghini, A.; Tamborini, E.; Lonardi, S.; Morano, F.; et al. Heterogeneity of Acquired Resistance to Anti-EGFR Monoclonal Antibodies in Patients with Metastatic Colorectal Cancer. Clin. Cancer Res. 2017, 23, 2414-2422. [CrossRef]

123. Kapitanovic, S.; Radosevic, S.; Kapitanovic, M.; Andelinovic, S.; Ferencic, Z.; Tavassoli, M.; Primorac, D.; Sonicki, Z.; Spaventi, S.; Pavelic, K.; et al. The expression of p185(HER-2/neu) correlates with the stage of disease and survival in colorectal can- cer. Gastroenterology 1997, 112, 1103-1113. [CrossRef]

124. Osako, T.; Miyahara, M.; Uchino, S.; Inomata, M.; Kitano, S.; Kobayashi, M. Immunohisto- chemical study of c-erbB-2 protein in colorectal can- cer and the correlation with patient survival. Oncology 1998, 55, 548-555. [CrossRef]

125. Song, Z.; Deng, Y.; Zhuang, K.; Li, A.; Liu, S. Immunohistochem- ical results of HER2/neu protein expression as- sessed by rabbit monoclonal antibodies SP3 and 4B5 in colorectal carcinomas. Int. J. Clin. Exp. Pathol. 2014, 7, 4454-4460. [PubMed]

126. Conradi, L.-C.; Styczen, H.; Sprenger, T.; Wolff, H.A.; Rödel, C.; Nietert, M.; Homayounfar, K.; Gaedcke, J.; Kitz, J.; Talaulicar, R.; et al. Frequency of HER-2 positivity in rectal cancer and prognosis. Am. J. Surg Pathol. 2013, 37, 522-531. [CrossRef] [PubMed]

127. Kruszewski, W.J.; Rzepko, R.; Ciesielski, M.; Szefel, J.; Zieliński, J.; Szajewski, M.; Jasiński, W.; Kawecki, K.; Wojtacki, J. Expression of HER2 in colorectal cancer does not correlate with prognosis. Dis Markers 2010, 29, 207-212. [CrossRef] [PubMed]

128. Laurent-Puig, P.; Balogoun, R.; Cayre, A.; Le Malicot, K.; Tabernero, J.; Mini, E.; Folprecht, G.; Van Laethem, J.-L.; Thaler, J.; Petersen, L.N.; et al. ERBB2 alterations a new prognostic biomarker in stage III colon cancer from a FOLFOX based adjuvant trial (PETACC8). Ann. Oncol. 2016, 27 (Suppl. S6), vi151. [CrossRef]

129. Wu, S.-W.; Ma, C.-C.; Li, W.-H. Does overexpression of HER-2 correlate with clinicopathological characteristics and prognosis in colorectal cancer? Evidence from a meta-analysis. Diagn. Pathol. 2015, 10, 144.

130. Khelwatty, S.; Puvanenthiran, S.; Essapen, S.; Bagwan, I.; Seddon, A.; Modjtahedi, H. HER2 Expression Is Predictive of Survival in Cetuximab Treated Patients with RAS Wild Type Metastatic Colorectal Cancer. Cancers 2021, 13, 638. [CrossRef]

131. Luca, T.; Barresi, V.; Privitera, G.; Musso, N.; Caruso, M.; Condorelli, D.F.; Castorina, S. In vitro combined treatment with cetuximab and trastuzumab inhibits growth of colon cancer cells. Cell Prolif. 2014, 47, 435-447. [CrossRef]

132. Leto, S.M.; Sassi, F.; Catalano, I.; Torri, V.; Migliardi, G.; Zanella, E.R.; Throsby, M.; Bertotti, A.; Trusolino, L. Sustained inhibition of HER3 and EGFR is necessary to induce regression of HER2-amplified gastrointestinal carcinomas. Clin. Cancer Res. 2015, 21, 5519-5531. [CrossRef] [PubMed]

133. Kloth, M.; Ruesseler, V.; Engel, C.; Koenig, K.; Peifer, M.; Mariotti, E.; Kuenstlinger, H.; Florin, A.; Rommerscheidt-Fuss, U.; Koitzsch, U.; et al. Activating ERBB2/HER2 mutations indicate susceptibility to pan-HER inhibitors in lynch and lynch-like colorectal cancer. Gut 2016, 65, 1296-1305. [CrossRef] [PubMed]

134. Rubinson, D.A.; Hochster, H.S.; Ryan, D.P.; Wolpin, B.M.; McCleary, N.J.; Abrams, T.A.; Chan, J.A.; Iqbal, S.; Lenz, H.J.; Lim, D.; et al. Multi-drug inhibition of the HER2 pathway in metastatic colorectal cancer: Results of a phase I study of pertuzumab plus cetuximab-refractory patients. Investig. New Drugs 2014, 32, 113-122. [CrossRef]

135. Ramanathan, R.K.; Hwang, J.J.; Zamboni, W.C.; Sinicrope, F.A.; Safran, H.; Wong, M.K.; Earle, M.; Brufsky, A.; Evans, T.; Troetschel, M.; et al. Low overexpression of HER-2/neu in advanced colorectal cancer limits the usefulness of trastuzumab (Herceptin) and irinotecan as therapy. A Phase II Trial. Cancer Investig. 2004, 22, 858-865. [CrossRef] [PubMed]

136. Clark, J.W.; Niedzwiecki, D.; Hollis, D.; Mayer, R. Phase II trial of \%-fluorouracil (5-FU), leucovorin (LV), oxaliplatin (Ox), and trastuzumab (T) for patients with metastatic colorectal cancer (CRC) refractory to inizial therapy. Onkologie 2003, 26 (Suppl. S3), $13-46$.

137. Bekaii-Saab, T.S.; Roda, J.M.; Guenterberg, K.D.; Ramaswamy, B.; Young, D.C.; Ferketich, A.K.; Lamb, T.A.; Grever, M.R.; Shapiro, C.L.; Carson, W.E. A phase I trial of paclitaxel and trastuzumab in combination with interleukin-12 in patients with HER2/neu-expressing malignancies. Mol. Cancer Ther. 2009, 8, 2983-2991. [CrossRef]

138. Deeken, J.F.; Wang, H.; Subramaniam, D.; He, A.R.; Hwang, J.; Marshall, J.L.; Urso, C.E.; Wang, Y.; Ramos, C.; Steadman, K.; et al. A phase 1 study of cetuximab and lapatinib in patients with advanced solid tumor malignancies. Cancer 2015, 121, 1645-1653. [CrossRef] [PubMed]

139. Hurwitz, H.; Raghav, K.P.; Burris, H.A.; Kurzrock, R.; Sweeney, C.; Meric-Bernstam, F.; Vanderwalde, A.M.; Spigel, D.R.; Bose, R.; Fakih, M.; et al. Pertuzumab + Trastuzumab for HER2-amplified/overexpressed metastatic colorectal cancer (mCRC): Interim data from MyPathway. J. Clin. Oncol. 2017, 35 (Suppl. S4), 672. [CrossRef]

140. Hainsworth, J.D.; Meric-Bernstam, F.; Swanton, C.; Hurwitz, H.; Spigel, D.R.; Sweeney, C.; Burris, H.A.; Bose, R.; Yoo, B.; Stein, A.; et al. Targeted therapy for advanced solid tumors on the basis of molecular profiles: Results from MyPathway, an open-label, phase IIa multiple basket study. J. Clin. Oncol. 2018, 36, 536-542. [CrossRef] [PubMed]

141. Siravegna, G.; Sartore-Bianchi, A.; Nagy, R.J.; Raghav, K.; Odegaard, J.I.; Lanman, R.B.; Trusolino, L.; Marsoni, S.; Siena, S.; Bardelli, A. Plasma HER2 (ERBB2) copy number predicts response to HER2-targeted therapy in metastatic colorectal cancer. Clin. Cancer Res. 2019, 25, 3046-3053. [CrossRef]

142. Sartore-Bianchi, A.; Lonardi, S.; Martino, C.; Fenocchio, E.; Tosi, F.; Ghezzi, S.; Leone, F.; Bergamo, F.; Zagonel, V.; Ciardiello, F.; et al. Pertuzumab and trastuzumab emtansine in patients with HER2-amplified metastatic colorectal cancer: The phase II HERACLES-B trial. ESMO Open 2020, 5, e000911. [CrossRef] [PubMed] 
143. Mangiapane, L.R.; Nicotra, A.; Turdo, A.; Gaggianesi, M.; Bianca, P.; Di Franco, S.; Sardina, D.S.; Veschi, V.; Signore, M.; Beyes, S.; et al. PI3K-driven HER2 expression is a potential therapeutic target in colorectal cancer stem cells. Gut 2021. [CrossRef] [PubMed]

144. Siena, S.; Di Bartolomeo, M.; Raghav, K.; Masuishi, T.; Loupakis, F.; Kawakami, H.; Yamaguchi, K.; Nishina, T.; Fakih, M.; Elez, E.; et al. Trastuzumab deruxtecan (DS-8201) in patients with HER2-expressing metastatic colorectal cancer (DESTINYCRC01): A multicentre, open-label, phase 2 trial. Lancet Oncol. 2021, 22, 779-789. [CrossRef] 